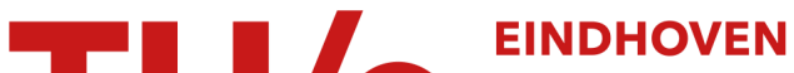 \\ UNIVERSITY OF \\ TECHNOLOGY
}

\section{Passivating contacts for crystalline silicon solar cells}

Citation for published version (APA):

Melskens, J., van de Loo, B. W. H., Macco, B., Black, L. E., Smit, S., \& Kessels, W. M. M. (2018). Passivating contacts for crystalline silicon solar cells: from concepts and materials to prospects. IEEE Journal of

Photovoltaics, 8(2), 373-388. https://doi.org/10.1109/JPHOTOV.2018.2797106

DOI:

10.1109/JPHOTOV.2018.2797106

Document status and date:

Published: 01/03/2018

\section{Document Version:}

Publisher's PDF, also known as Version of Record (includes final page, issue and volume numbers)

\section{Please check the document version of this publication:}

- A submitted manuscript is the version of the article upon submission and before peer-review. There can be important differences between the submitted version and the official published version of record. People interested in the research are advised to contact the author for the final version of the publication, or visit the $\mathrm{DOI}$ to the publisher's website.

- The final author version and the galley proof are versions of the publication after peer review.

- The final published version features the final layout of the paper including the volume, issue and page numbers.

Link to publication

\section{General rights}

Copyright and moral rights for the publications made accessible in the public portal are retained by the authors and/or other copyright owners and it is a condition of accessing publications that users recognise and abide by the legal requirements associated with these rights.

- Users may download and print one copy of any publication from the public portal for the purpose of private study or research.

- You may not further distribute the material or use it for any profit-making activity or commercial gain

- You may freely distribute the URL identifying the publication in the public portal.

If the publication is distributed under the terms of Article 25fa of the Dutch Copyright Act, indicated by the "Taverne" license above, please follow below link for the End User Agreement:

www.tue.nl/taverne

Take down policy

If you believe that this document breaches copyright please contact us at:

openaccess@tue.nl

providing details and we will investigate your claim. 


\title{
Passivating Contacts for Crystalline Silicon Solar Cells: From Concepts and Materials to Prospects
}

\author{
Jimmy Melskens ${ }^{(1)}$, Bas W. H. van de Loo ${ }^{(0)}$, Bart Macco, Lachlan E. Black, Sjoerd Smit, \\ and W. M. M. (Erwin) Kessels ${ }^{(0)}$
}

\begin{abstract}
To further increase the conversion efficiency of crystalline silicon (c-Si) solar cells, it is vital to reduce the recombination losses associated with the contacts. Therefore, a contact structure that simultaneously passivates the c-Si surface while selectively extracting only one type of charge carrier (i.e., either electrons or holes) is desired. Realizing such passivating contacts in c-Si solar cells has become an important research objective, and an overview and classification of work to date on this topic is presented here. Using this overview, we discuss the design guidelines for passivating contacts and outline their prospects.
\end{abstract}

Index Terms-Charge carrier lifetime, contacts, crystalline silicon (c-Si), passivation, photovoltaic (PV) cells.

\section{INTRODUCTION}

I $\mathrm{N}$ the ever-growing photovoltaic (PV) market, the so-called balance-of-system costs, such as mounting and framing materials, inverters, cabling, and labor, make up an increasingly large share of the overall price of PV systems [1]. Therefore, it is important to further increase the conversion efficiency of industrially viable solar cell concepts because this reduces the levelized cost of electricity. To accomplish further efficiency gains while approaching both the theoretical limit [2] and the practical limit [3]-[5] $]^{1}$ for single-junction crystalline silicon (c-Si) solar cells, recombination losses at the contacts need to be tackled, since these losses have become a limiting factor for both laboratory-scale and industrial solar cells. A traditional approach to this problem is the use of local contacts, as employed, for instance, in the well-known passivated emitter and rear cell (PERC) and related architectures, such as passivated emitter locally diffused (PERL) and passivated emitter rear totally

Manuscript received December 20, 2017; accepted January 16, 2018. Date of publication February 14, 2018; date of current version February 16, 2018. This work was supported by the Top consortia for Knowledge and Innovation Solar Energy programs "COMPASS," "RADAR," and "AAA" of the Ministry of Economic Affairs of The Netherlands. The work of J. Melskens was supported by the Netherlands Organisation for Scientific Research under the Dutch TTWVENI Grant 15896. (Corresponding author: Jimmy Melskens.)

The authors are with the Department of Applied Physics, Eindhoven University of Technology, Eindhoven MB 5600, The Netherlands (e-mail: j.melskens@tue.nl; b.w.h.v.d.loo@tue.nl; b.macco@tue.nl; 1.e.black@tue.nl; s.smit@tue.nl; w.m.m.kessels@tue.nl).

Color versions of one or more of the figures in this paper are available online at http://ieeexplore.ieee.org.

Digital Object Identifier 10.1109/JPHOTOV.2018.2797106

${ }^{1}$ Note that the theoretical limit calculation assumes no recombination losses at the surface or due to defects in the Si wafer and perfect Lambertian light trapping, while, in practice, such electrical and optical losses do occur, hence giving rise to the practical efficiency limit. A detailed assessment of the losses associated with the practical limit with respect to the current $\mathrm{c}$-Si record solar cell with an efficiency of $26.6 \%$ is given elsewhere [3], [5]. diffused (PERT) cells [6]. In these contact structures, the area of direct contact between the silicon and the metal is decreased, while the non-contacted area is covered by a passivating dielectric layer or layer stack. However, when forming local contacts, the processing complexity is increased, and lateral transport becomes a more critical factor in the solar cell design. More specifically, there is a tradeoff between the open-circuit voltage $\left(V_{\mathrm{oc}}\right)$ and the fill factor $(F F)$ due to increased Ohmic losses, which are induced by lateral electrical transport [7].

An alternative approach to reduce contact recombination losses is the use of the so-called passivating contacts. These consist of material structures placed between c-Si and the metal electrode, which effectively suppress charge carrier recombination through defect states at the c-Si surface while simultaneously functioning as contacts to extract either electrons or holes from the c-Si absorber. Due to the lower recombination losses associated with such passivating contacts, they can be used in full-area configurations. Therefore, the use of a separate passivation layer and local metal contacts can be avoided. In this way, passivating contacts hold the potential for simplified solar cell manufacturing while providing very high conversion efficiencies. Indeed, the potential of passivating contact approaches has been demonstrated by conversion efficiencies of more than $25 \%$ for solar cells utilizing hydrogenated amorphous silicon (a-Si:H) heterojunction ( $\mathrm{SHJ}$ ) contacts (historically referred to as heterojunction with intrinsic thin layer) or contacts consisting of an ultrathin silicon oxide $\left(\mathrm{SiO}_{\mathrm{x}}\right)$ layer together with doped polycrystalline silicon (poly-Si) [3], [5], [7]-[11].

A significant amount of work has already been done in the field of passivating contacts, as is, for instance, demonstrated by the high solar cell conversion efficiencies enabled by the SHJ and oxide/poly-Si contact approaches mentioned above. However, in recent years, there has been a significant research effort focused on new passivating contact structures and materials as well. These materials are of interest, as they can provide advantages in terms of, e.g., temperature stability or transparency over the SHJ or oxide/poly-Si concepts. Various overviews of various passivating contact materials and concepts have recently been presented with a particular focus on certain promising passivating contact materials [12]-[18]. In this contribution, we not only review the working principles and performance of existing passivating contact approaches, but elaborate on promising emerging materials in terms of optical and electrical properties and industrial applicability as well. Finally, an overview of some remaining challenges for passivating contacts is provided and their future prospects are outlined. 


\section{Passivating Contact Definition And ConcePts}

Before describing specific passivating contact materials and structures (see Section III), in this section, the definition of a passivating contact, the relevant figures of merit, and the different conceptual approaches to realizing such contacts are considered. This section is intended only to provide a summary of this topic so as to form the context for subsequent discussion. Therefore, we do not discuss the physical theory in detail. For an elegant and more detailed description of the physics of passivating contacts, the reader is referred to the work of Würfel et al. [19].

An ideal passivating contact consists of a structure formed at the surface of a semiconductor, which combines the functions of a passivation layer and a contact. That is, it simultaneously minimizes charge carrier recombination losses associated with the surface and within the contact structure itself, while permitting the efficient extraction of charge from the semiconductor by an external circuit. In order to combine these functions, this charge extraction must be selective with respect to carrier type, i.e., the conductivity for one carrier type (electrons or holes) must be much higher than it is for the other. Otherwise, excess majority and minority carriers will be extracted with too similar probability and will recombine at the electrode [20]. The ideal passivating contact may, therefore, be thought of as a semipermeable membrane, which transmits one type of carrier and blocks the other [19]. Note that we specifically choose to use the term passivating contacts (as opposed to passivated contacts) to emphasize that surface passivation is a primary function of these contacts. Finally, in addition to the electrical properties, the optical losses should be minimized both on the front and rear sides of the solar cell for any contact structure [21].

The quality of a contact in a c-Si solar cell may be characterized by the recombination current density prefactor $J_{0}$ (with units of current per unit area) and the contact resistivity $\rho_{\text {contact }}$ (with units of resistance times area). It is desirable to minimize both of these parameters. Practical contacts are, of course, characterized by non-zero values of $J_{0}$ and $\rho_{\text {contact }}$, and commonly, one of the two may be more limiting for the device performance. In c-Si solar cell technology in general, it may, therefore, be advantageous to trade off the relative influence of $J_{0}$ (representing recombination losses) and $\rho_{\text {contact }}$ (representing resistive losses) on cell efficiency, which is possible by varying the contact area fraction. This approach is exemplified by the use of local contacts in cell structures such as PERC [6], where it is possible to compensate a relatively high $J_{0}$ at the c-Si/metal contact by reducing the contact area (and applying a passivating dielectric in between the contacts) due to the relatively low $\rho_{\text {contact }}$. Another type of tradeoff between $J_{0}$ and $\rho_{\text {contact }}$ may be realized by uniformly reducing the conductivity of the contact for both carrier types, for example, by the insertion of an interfacial dielectric tunnel barrier that improves the interface passivation, thereby reducing $J_{0}$ while increasing $\rho_{\text {contact }}$. This is the tradeoff embodied in the use of metal-insulatorsemiconductor (MIS) contact structures [22]. Note that such an interfacial layer may also contribute to selectivity if it induces band bending in the silicon or presents an asymmetrical tunnel barrier to electrons and holes, as discussed in the following.
$J_{0}$ and $\rho_{\text {contact }}$ are somewhat interrelated through their mutual dependence on the conductivity of the contact for electrons $\left(\sigma_{n}\right)$ and for holes $\left(\sigma_{p}\right) . J_{0}$ depends not only on the quality of the interface passivation, but on the conductivity for minority carriers in the contact as well, i.e., those carriers that are not supposed to be collected by the contact, since minority carriers transported to the metal electrode will recombine there. Therefore, it is particularly relevant to evaluate $J_{0}$ after metallization [23]. On the other hand, $\rho_{\text {contact }}$ scales inversely with the sum of the conductivities for both carriers. Therefore, to minimize both $J_{0}$ and $\rho_{\text {contact }}$ simultaneously, it is necessary to maximize the conductivity of majority carriers in the contact and minimize the conductivity of minority carriers in the contact at the same time. The ratio of these conductivities defines the charge carrier selectivity of the contact. This illustrates why achieving a high selectivity is a necessary (though not sufficient) condition for realizing a good passivating contact.

There are several conceptual approaches to achieving the desired carrier selectivity. The most common approach to make a contact carrier-selective is to introduce heavy doping in the c-Si, as is commonly done in homojunction solar cells, for example, in solar cells with a so-called aluminum back-surface-field (AlBSF). An example of an electron-selective contact made this way is depicted in Fig. 1(a). The additional doping strongly reduces the minority carrier conductivity by: 1) reducing the equilibrium concentration of minority carriers due to the difference in chemical potential with respect to the c-Si bulk; and 2 ) reducing the minority carrier mobility [24]. This allows a relatively low $J_{0}$ to be achieved even when the defect concentration at the $\mathrm{c}-\mathrm{Si} / \mathrm{metal}$ interface is very high. At the same time, the majority carrier conductivity is increased due to the large majority carrier concentration, leading to a low contact resistivity.

A second approach to achieve carrier selectivity is to modulate the surface carrier concentrations and, hence, their conductivities by the application of an external potential source, such as a low- or high-work-function (WF) metal (oxide) or a material with a large fixed charge density $\left(Q_{\mathrm{f}}\right)$, as shown in Fig. 1(b). Practical examples of contacts that rely on this selectivity mechanism will be discussed in the next section.

A third way to realize a selective contact is by the formation of a heterojunction between the silicon substrate and a widebandgap material with the desired conductivity type ( $n$ or $p$ ), making sure that the conduction (for $n$ ) or valence (for $p$ ) band offset between the two materials is sufficiently small while ensuring a suitable Fermi level alignment, so as not to form a potential barrier for majority carrier transport. In this situation, the concentration of minority carriers in the contact material is strongly suppressed due to its wider bandgap and large majority carrier concentration, which induces carrier selectivity. An idealized case of such a heterojunction contact is shown in Fig. 1(c). This structure has the advantage over the homojunction approach of increased selectivity potential due to the wider bandgap of the conductive layer with respect to $\mathrm{c}-\mathrm{Si}$. A well-known example of such a contact structure is the classical c-Si/a-Si:H heterojunction [25]. Hereby, it should be noted that the doping that is present in $p$-type or $n$-type doped a-Si:H, as commonly used in classical SHJ solar cells, induces carrier selectivity as a consequence of WF-induced band bending, in 


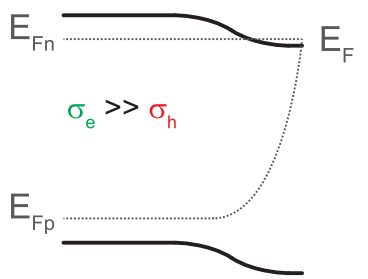

(a)

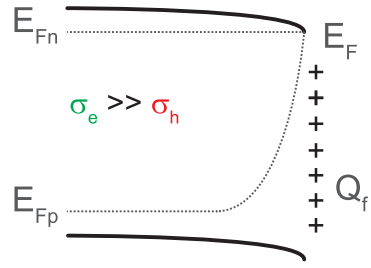

(b)

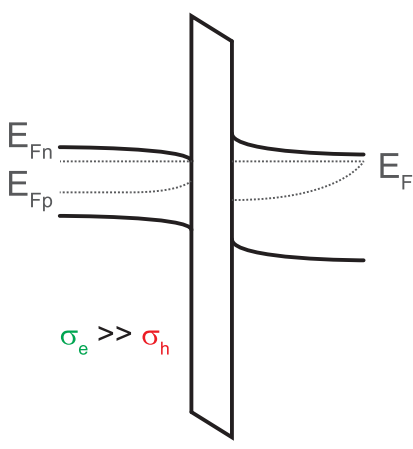

(d)
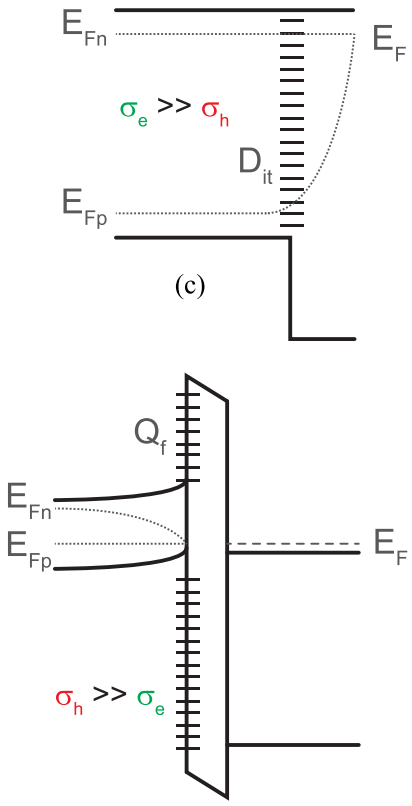

(e)
Fig. 1. Schematic idealized band diagrams for examples of selective contact concepts on $n$-type c-Si under open-circuit conditions. The contact can be made electron-selective (a) by introducing an $n^{+}$doping in the c-Si wafer, (b) by modifying the surface carrier concentrations and, hence, their conductivities by an external potential source, or (c) by forming a heterojunction with a wide-bandgap material, which possesses a conduction band alignment and a suitable Fermi level alignment with c-Si. Examples of tunnel contacts formed by inserting an ultrathin, wide-bandgap dielectric (d) between $n$-Si and a heavily doped $n$-type semiconductor or (e) between $n$-Si and a degenerately doped $n$ type semiconductor, exploiting the fixed charge in the tunnel oxide to form a structure analogous to an Esaki tunnel diode. The metal electrode is not shown but is consistently positioned on the far right in band diagrams (a)-(e). The conductivity labels refer to the contact as a whole and not to one particular region of the contact.

analogy to the case shown in Fig. 1(b). Therefore, the selectivity provided by doped a-Si:H can be considered a combination of the cases illustrated in Fig. 1(b) and (c).

Finally, a selective contact structure may be formed by introducing a tunnel barrier (such as an ultrathin dielectric layer) with an asymmetrical tunneling probability for electrons and holes (due to, e.g., variation of potential barrier heights or tunneling effective mass). For example, thin $\mathrm{SiO}_{2}$ layers have been shown to present a larger tunneling barrier for holes than for electrons [26].

In practice, passivating contact structures may employ more than one of these selectivity mechanisms and may be constructed of multiple material layers performing different functions. For instance, apart from their potential contribution to selectivity through possible fixed charge or asymmetric barrier properties, ultrathin dielectric layers may be employed at the interface between c-Si and an already carrier-selective conductive layer to passivate interface defect states, as illustrated in Fig. 1(d). This is the case, for example, in oxide/poly-Si contact structures. Such interface states would, otherwise, act as a source of charge carrier recombination and contribute to Fermi level pinning, which may be detrimental to selectivity. Structures based on different band alignments than what is shown in Fig. 1(a)-(c) are also possible. For example, $n$-Si in contact with a degenerately doped $n$-type semiconductor with suitable band alignment or interface charge may form a hole-selective contact structure analogous to an Esaki tunnel diode [27], with current transport between the $\mathrm{c}-\mathrm{Si}$ valence band and the conduction band of the contacting material, as illustrated in Fig. 1(e). Selectivity in this case comes from the increased hole concentration at the c-Si surface induced by the WF difference between the materials or the fixed charge at the interface (i.e., the second mechanism discussed above, visualized in Fig. 1(b).

Additional combinations and variations may also be possible, but will not be discussed in further detail here. Note that in Fig. 1 we mostly show examples of electron-selective contacts on $n$ $\mathrm{Si}$, while analogous hole-selective contacts may be realized in a similar manner, and both types of contact may, in principle, be applied to either $n$-Si or $p$-Si surfaces.

\section{Passivating Contact Materials And Structures}

As should be clear from the discussion of Fig. 1, it is imperative that passivating contacts are engineered while carefully considering the band alignments of possible contact configurations and combinations of materials. Apart from the passivation that is provided by a given material, it is necessary to assess whether a material (or a stack of materials) is able to provide selectivity for one type of charge carrier. In that context, it is insightful to consider the band offsets and WFs of various materials with c-Si. An overview of the band offsets with respect to c-Si for a selection of different candidate materials that have been evaluated as (part of) a passivating contact is shown in Fig. 2. Note that some of the offset values shown have been obtained from theoretical predictions $\left(\mathrm{HfO}_{2}\right.$ [28], [29], $\mathrm{Ta}_{2} \mathrm{O}_{5}$ [28]-[30], $\mathrm{MoO}_{3}$ [29]-[31], and $\mathrm{WO}_{3}$ [30], [31]) and some from experimental observations $\left(\mathrm{SiO}_{2}\right.$ [32], $\mathrm{Al}_{2} \mathrm{O}_{3}$ [28], [33], a-Si:H [34], $\mathrm{TiO}_{2}$ [35], [36], $\mathrm{NiO}$ [37], PEDOT:PSS [38], [39], $\mathrm{In}_{2} \mathrm{O}_{3}$ [40], and $\mathrm{ZnO}$ [40]), considering a heterojunction with silicon whenever such data are available [32]-[35], [38], [39]. For a-Si:H, the variation in conduction and valence band offsets has been carefully determined for a wide variety of plasmaenhanced chemical vapor deposition (PECVD) conditions that yield a-Si:H with significantly different material properties [34]. It should be noted that band offsets are usually calculated by taking the vacuum potential as the reference energy level-a method known as Anderson's rule [41] — while the band offset between two materials is also influenced by the properties of their interface [42], [43]; therefore, the vacuum-referenced values only give a rough indication of the alignment. Band offsets (and WFs) will also depend somewhat on the exact composition and structure of each material, which will depend on the preparation method. 


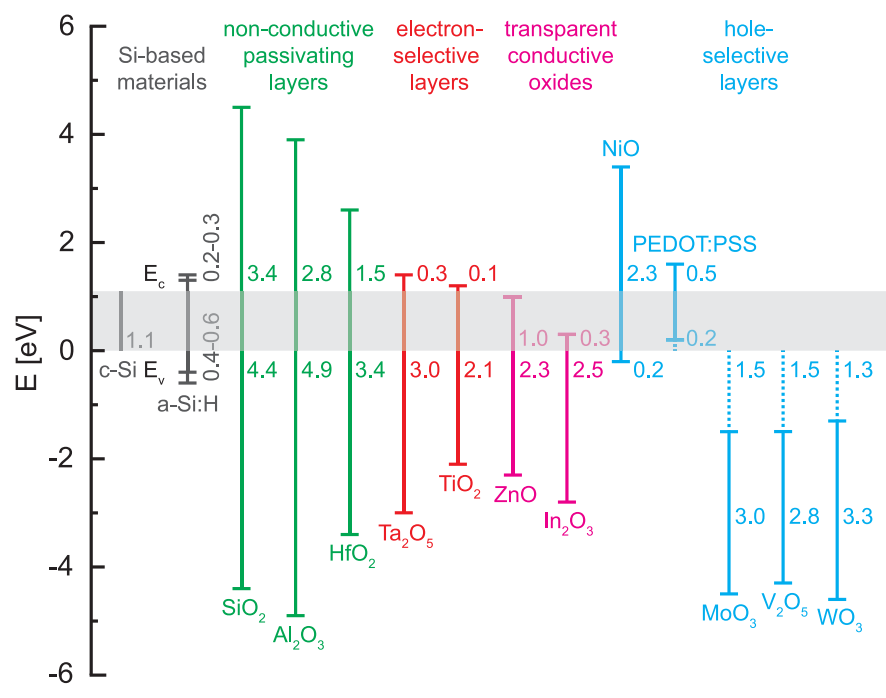

Fig. 2. Conduction and valence band offsets of various materials with respect to $\mathrm{c}-\mathrm{Si}$. For materials that have an electron affinity greater than that of $\mathrm{c}-\mathrm{Si}$ (TCOs, $\mathrm{MoO}_{3}, \mathrm{~V}_{2} \mathrm{O}_{5}$, and $\mathrm{WO}_{3}$ ), the energetic difference between the conduction band of those materials and the c-Si valence band is shown. All numerical values shown are expressed in electronvolts. Note that all values should be taken as indicative only, since the exact values will depend on aspects such as the deposition method, stoichiometry, and the doping level of the material.

While accepting the uncertainties associated with band offset values as outlined above, it is clear from Fig. 2 which materials potentially exhibit a small conduction band offset $\left(\mathrm{Ta}_{2} \mathrm{O}_{5}\right.$, $\mathrm{TiO}_{2}, \mathrm{ZnO}$ ) or a small valence band offset (NiO, PEDOT:PSS) with respect to c-Si and can, therefore, potentially serve as an electron-selective or a hole-selective contact, respectively. This does, however, not mean that carrier selectivity depends solely on band alignment, since the WF of the material can also induce selectivity, as was discussed in Section II. The WF values for the transition metal oxides can range from 3.5 to $7 \mathrm{eV}$ and can be influenced by the structure and composition of the material, in particular the stoichiometry, and the presence of dopants [30]. Because the WF values can vary widely for different materials, they are not shown in Fig. 2, although they play a critical part in achieving carrier selectivity for certain materials that do not exhibit a conduction or valence band alignment with c-Si, such as $\mathrm{MoO}_{\mathrm{x}}, \mathrm{VO}_{\mathrm{x}}, \mathrm{WO}_{\mathrm{x}}$, and (doped) a-Si:H.

A few examples of non-conductive passivating layers are shown in Fig. 2. Due to the large valence and conduction band offsets, it is clear that none of the passivating dielectric layers that are shown in green in Fig. 2 can render a carrier-selective contact by themselves despite their passivating qualities. However, these dielectrics can be interesting candidate materials in tunneling contacts. Finally, some examples of materials traditionally employed as transparent conductive oxides (TCOs) are shown in Fig. 2, since these are expected to play a role as lateral conductors in many passivating contact structures, in which role their band alignment and WF alignment with the passivating contact structure are relevant. These materials may also be capable of forming hole-selective or electron-selective contacts in their own right when the band alignment is suitable, as appears to be the case for $\mathrm{ZnO}$ as an electron-selective contact.

A wide variety of materials and structures have been investigated for passivating contact applications and the list of these is increasing rapidly. In order to provide an overview of these developments, we make the following division of passivating contact materials based on their chemical nature: Si-based materials, transition metal oxides, organics, and alkali/alkaline metals, oxides, and salts. These materials will be discussed separately in the following subsections.

\section{A. Si-Based Materials}

The classical SHJ contact structure has resulted in the most efficient c-Si solar cells reported so far of $26.6 \%$ [3], [5]. This is enabled by the excellent properties of this structure, which comprises a thin intrinsic a-Si:H layer that is deposited on the c-Si surface by PECVD, followed by a layer of either $p$-type or $n$-type doped a-Si:H. First, the intrinsic a-Si:H layer provides chemical passivation of the c-Si surface [44]. Second, the doped a-Si:H layers provide carrier selectivity by inducing band bending in the c-Si [see Fig. 1(b)]. Additionally, the heavy doping yields an asymmetry in the conduction of electrons and holes, which is an effect that is further aided by the fact that a-Si:H has a wider bandgap than c-Si [as in Fig. 1(c)] [19], [45]. As the lateral conduction through a-Si:H is quite poor, TCOs are typically used on top of the a-Si:H(i)/a-Si $(p / n)$ layers, while the TCO layer on the front side of the solar cell moreover functions as an antireflection coating (ARC).

Although SHJ solar cells can enable high conversion efficiencies, there are also some downsides associated with the use of a-Si:H. For instance, significant optical absorption losses are associated with the a-Si:H layers [46], as will be further discussed in Section IV. Furthermore, the a-Si:H layers are not very thermally stable. Although the passivation quality provided by a-Si:H can improve when annealing for a few minutes at $300^{\circ} \mathrm{C}$ [47], large concentrations of defects are typically formed when annealing a-Si:H on longer timescales already at lower temperatures such as $200{ }^{\circ} \mathrm{C}$ [25], [48]. Especially in the case of $p$-type a-Si:H, the passivation quality can be easily damaged during annealing due to $\mathrm{H}$ effusion that is caused by $\mathrm{Si}-\mathrm{H}$ bond breakage [49]. Therefore, subsequent solar cell manufacturing steps have to be carried out at low temperatures, which, for instance, rules out the use of high-temperature firing steps $\left(>700{ }^{\circ} \mathrm{C}\right)$ typically employed in other solar cell concepts.

Another Si-based contact is the $\mathrm{SiO}_{\mathrm{x}} /$ poly-Si structure. This type of contact is a long-known technology in the semiconductor industry that has recently emerged as a highly promising passivating contact for c-Si solar cells. The first attempts using semi-insulating poly-Si technology originate from its implementation in bipolar junction transistors in the 1970s [50], when it was established that poly-Si can provide improved contact quality when combined with $\mathrm{SiO}_{\mathrm{x}}$ due to Fermi level depinning and reduced recombination losses. It was around the same time when a growing interest appeared in the classical MIS contact, in which an ultrathin dielectric layer was inserted between a metal and the silicon wafer to mitigate recombination losses, while still allowing transport through the dielectric and attempting to retain charge carrier selectivity [22]. However, initially, it turned out to be challenging to achieve good surface passivation with ultrathin $\mathrm{SiO}_{\mathrm{x}}$. Recently, an ultrathin $(<1.5 \mathrm{~nm}) \mathrm{SiO}_{\mathrm{x}}$ layer has been successfully combined with doped poly-Si to form a passivating contact structure that has 
enabled solar cell conversion efficiencies exceeding $25 \%$, while using full-area contacts instead of local contacts [7], [11], [51][53]. Note that while very low $J_{0}$ values have been reported for both $n$-type and $p$-type poly-Si in combination with an ultrathin $\mathrm{SiO}_{\mathrm{x}}$ layer $\left(J_{0}=2-8 \mathrm{fA} / \mathrm{cm}^{2}\right)$, a better performance has so far been achieved for the phosphorus-doped poly-Si when compared to boron-doped poly-Si [54]. Note that solar cells with this type of oxide/poly-Si contacts are sometimes described by the acronyms TOPCon (tunnel oxide passivated contact) [7], [11], [51], [52] or POLO (poly-Si on oxide) [53].

The working mechanism of this passivating contact structure is based on two aspects. First, the ultrathin oxide, which is typically grown by chemical or thermal oxidation, provides chemical passivation at the $\mathrm{c}$-Si/oxide interface, resulting in a low $D_{\text {it }}$, and acts as a barrier toward dopant diffusion from poly-Si to c-Si, while still enabling charge transfer from c-Si to poly-Si. Second, the doping present in the poly-Si increases the conductivity of one type of charge carrier, while the conductivity of the other charge carrier type is reduced. Note that poly-Si can be grown directly or formed after crystallization of a-Si:H using either PECVD or low-pressure chemical vapor deposition (LPCVD). The doping can be introduced either in situ (during deposition) or ex situ by means of ion implantation or diffusion. Furthermore, it is crucial that defects at the c-Si/SiO ${ }_{x}$ interface are passivated. This can be achieved by hydrogenating the polySi layer by means of hydrogen plasma treatments [55] or by capping the poly-Si layer with $\mathrm{Al}_{2} \mathrm{O}_{3}$ [56] or $\mathrm{SiN}_{\mathrm{x}}$ [57]. The band diagram that visually illustrates the working mechanism of an electron-selective passivating contact based on $n$-type poly-Si is shown in Fig. 1(d).

$\mathrm{SiO}_{\mathrm{x}} /$ poly-Si contacts have the significant advantage that they are more thermally stable than the a-Si:H-based contacts that are used in classical SHJ solar cells. However, compared to the classical SHJ solar cell, the oxide/poly-Si approach requires high-temperature processing $\left(\sim 900^{\circ} \mathrm{C}\right)$ to achieve the necessary material properties for the passivating contact, in particular to achieve the desired doping level in the poly-Si layer.

Although the potential of the oxide/poly-Si approach has been demonstrated, key physical aspects of the ultrathin oxide layer are still under discussion, such as the ideal oxide thickness, the oxide stoichiometry, and the charge transport mechanism through the oxide. Especially on the latter aspect no consensus has been reached yet. Traditionally, direct or trap-assisted tunneling is considered to be the responsible carrier transport mechanism through an ultrathin oxide [58], [59], which is supported by numerical simulations [60]. However, it has recently been argued that conduction via pinholes in the oxide could be responsible for the carrier transport in the oxide [61], [62] or that it should be seen as a combination of tunneling and pinholeassisted transport [63]. Since the oxide thickness varies in different implementations of $\mathrm{SiO}_{\mathrm{x}} /$ poly-Si contacts, e.g., $1.4 \mathrm{~nm}$ [11], $2.1 \mathrm{~nm}$ [53], or even $3.6 \mathrm{~nm}$ [64], it should be noted that tunneling becomes less likely in the case of thicker oxides, since tunneling is assumed to take place when the oxide is thin enough, i.e., $<2 \mathrm{~nm}$ [63]. Furthermore, possible improvements in the oxide growth as well as the poly-Si growth and doping methods are being explored to further enhance the performance of solar cells with oxide/poly-Si contacts [51], [52], [65]-[69].
A significant drawback of the oxide/poly-Si approach is the fact that poly-Si has a similar bandgap to c-Si. Therefore, when using doped poly-Si on the front side of the solar cell, this is expected to result in relatively large absorption losses, as will be discussed in the next section. Additionally, poly-Si is typically heavily doped in order to create a good contact in terms of carrier selectivity, but heavy doping also results in free-carrier absorption (FCA) [70], similar to what is observed for highly doped c-Si [71]. This FCA still plays a role when poly-Si is applied at the rear side of the solar cell.

Given the significant absorption losses associated with a-Si:H and poly-Si, the use of more transparent carrier-selective materials is an attractive approach to further increase the solar cell efficiency. A potential Si-based candidate that circumvents the typically high absorption losses associated with a-Si:H and poly-Si is hydrogenated nanocrystalline silicon (nc-Si:H)—sometimes referred to as hydrogenated microcrystalline silicon-which is typically prepared by PECVD [72], [73] or hot wire chemical vapor deposition (HWCVD) [74]. Although the same carrier selectivity mechanisms apply to a-Si:H, poly-Si, and nc-Si:H, the latter has some distinct advantages in addition to the higher transparency. More specifically, nc-Si:H enables a higher doping efficiency, a lower contact resistivity, and a suppressed Schottky barrier at the interface with an adjacent TCO compared with a-Si:H, thus improving the contact quality [72], [73]. nc-Si:H has been thoroughly investigated in the field of thin-film silicon solar cells with a particular focus on achieving a high electrical quality of the bulk at a high deposition rate to grow layers with a thickness in the order of micrometers [75], [76]. However, when using this material in SHJ solar cells, a typical thickness of only $\sim 10 \mathrm{~nm}$ is desired. This implies that it is more critical to suppress the formation of an a-Si:H incubation layer, achieve sufficiently high crystallinity, and avoid damage to underlying passivating layers and the c-Si substrate [77]. When these issues are properly addressed, it is possible to achieve solar cell efficiencies around $21 \%$, largely owing to high $J_{\text {sc }}$ and $F F$ values due to high transparency and a low $\rho_{\text {contact }}$ value, respectively [72], [73]. The transparency advantage of nc-Si:H can be further exploited when alloying the material with oxygen, thus forming hydrogenated nanocrystalline silicon oxide $\left(\mathrm{nc}^{-\mathrm{SiO}_{\mathrm{x}}}: \mathrm{H}\right)$. When using $p$-type $\mathrm{nc}^{-\mathrm{SiO}_{\mathrm{x}}}: \mathrm{H}$ instead of $p$-type a-Si:H as the hole-selective layer in a SHJ solar cell, a large $J_{\mathrm{sc}}$ improvement of $1.7 \mathrm{~mA} / \mathrm{cm}^{2}$ up to $40.4 \mathrm{~mA} / \mathrm{cm}^{2}$ has been demonstrated [77]. Alternatively, a stack of an ultrathin $\mathrm{SiO}_{\mathrm{x}}$ layer and hydrogenated nanocrystalline silicon carbide $\left(\mathrm{nc}-\mathrm{SiC}_{\mathrm{x}}: \mathrm{H}\right)$ can provide excellent surface passivation after postdeposition annealing at high temperatures without using an a-Si:H interlayer [74]. This contact stack can be used to form a hole-selective passivating contact, as is illustrated by excellent values of both $J_{0}\left(9 \mathrm{fA} / \mathrm{cm}^{2}\right.$ on $n$-type $\mathrm{Si}$; $11 \mathrm{fA} / \mathrm{cm}^{2}$ on $p$-type $\left.\mathrm{Si}\right)$ and $\rho_{\text {contact }}\left(86 \mathrm{~m} \Omega \cdot \mathrm{cm}^{2}\right.$ on $n$-type $\mathrm{Si}$; $19 \mathrm{~m} \Omega \cdot \mathrm{cm}^{2}$ on $p$-type $\mathrm{Si}$ ) [78]. Its material and contact properties are comparable with the previously discussed $\mathrm{SiO}_{\mathrm{x}} /$ poly-Si structure, and it is compatible with high-temperature metallization schemes. Unfortunately, limited transparency is also a common factor for these two contact structures, practically restricting the use of $\mathrm{SiO}_{\mathrm{x}} / \mathrm{SiC}_{\mathrm{x}}$ contacts to the rear side of the solar cell. Yet, when using this contact in a solar cell with an a-Si:H-based electron-selective contact on the front side of the 
cell, conversion efficiencies of $20.4 \%$ [79] and $21.9 \%$ [80] have been achieved. These recent results underline the potential of this approach.

\section{B. Transition Metal Oxides}

Recently, transition metal oxides have been gaining increased attention in passivating contact materials research, which is driven by their excellent transparency (typically $E_{\mathrm{g}}>3 \mathrm{eV}$ ), the possibility of low-temperature deposition (unlike poly-Si), and a potentially better thermal stability than a-Si:H. Additionally, the wide bandgap can be helpful in realizing sufficient carrier selectivity even when using layers of only a few nanometers thick. Although some of these metal oxides are already known as carrier-selective contacts in the field of organic and perovskite photovoltaics, such as titanium oxide $\left(\mathrm{TiO}_{\mathrm{x}}\right)$ [81]-[83] and molybdenum oxide $\left(\mathrm{MoO}_{\mathrm{x}}\right)$ [84], [85], they are relatively new as contact materials in c-Si solar cells. ${ }^{2}$

Perhaps the most promising results for transition metal oxides as passivating contacts in $\mathrm{c}-\mathrm{Si}$ solar cells have been achieved for titanium oxide $\left(\mathrm{TiO}_{\mathrm{x}}\right)$ as electron-selective material. $\mathrm{TiO}_{\mathrm{x}}$ is well known as an ARC for c-Si solar cells and was the dominant material used for this purpose from the early 1970s through the late 1990s, when it was replaced by $\mathrm{SiN}_{\mathrm{x}}$ due to the superior c-Si surface passivation provided by the latter. Good surface passivation of both $p$ - and $n$-type c-Si $\left(\tau_{\text {eff }}>1 \mathrm{~ms}\right)$ has only recently been reported for $\mathrm{TiO}_{\mathrm{x}}$ prepared by atomic layer deposition (ALD), after annealing and light soaking treatments [86]. These findings, together with the demonstration of electronselective contact properties for $\mathrm{Al} / \mathrm{TiO}_{\mathrm{x}}(3 \mathrm{~nm}) / \mathrm{c}$-Si structures [35], triggered increased interest in $\mathrm{TiO}_{\mathrm{x}}$ as a candidate electronselective contact material [86]-[89]. As a part of this research effort, very low $J_{0}$ values of $6-8 \mathrm{fA} / \mathrm{cm}^{2}$ have since been reported for $\mathrm{TiO}_{\mathrm{x}}$ layers on $p$ - and $n$-type float-zone c-Si without any postdeposition treatment, such as annealing or light soaking [87]. Furthermore, a low contact resistivity of $20 \mathrm{~m} \Omega \cdot \mathrm{cm}^{2}$ has been reported for an $\mathrm{Al} / \mathrm{TiO}_{\mathrm{x}}(2.5 \mathrm{~nm}) / \mathrm{c}-\mathrm{Si}$ structure [90], while the value of $\rho_{\text {contact }}$ increased strongly for increasing $\mathrm{TiO}_{\mathrm{x}}$ thickness.

$\mathrm{TiO}_{\mathrm{x}}$ is particularly interesting as an electron-selective contact because the conduction band offset can be as small as $0.1 \mathrm{eV}$, while the valence band offset is approximately $2.1 \mathrm{eV}$, which yields an alignment of the c-Si and $\mathrm{TiO}_{\mathrm{x}}$ conduction bands, as shown in Figs. 1(c) and 2 [35], [36]. It should be noted that this electron selectivity is apparently achieved despite the negative charge inferred by most investigators for surface-passivating $\mathrm{TiO}_{\mathrm{x}}$ [86], [87], [91]. It has been argued that negative charges can appear at the $\mathrm{TiO}_{\mathrm{x}}$ surface as a consequence of redox reactions and also that light soaking results in negative charging [86], [91], which may be detrimental when aiming to fabricate a $\mathrm{TiO}_{\mathrm{x}}$-based electron-selective contact. On the other hand, it has

\footnotetext{
${ }^{2}$ The metal oxide layers in perovskite solar cells are typically thicker (e.g., $11 \mathrm{~nm}$ of $\mathrm{ALD} \mathrm{TiO}_{\mathrm{x}}$ [82] or $60 \mathrm{~nm}$ of e-beam evaporated $\mathrm{TiO}_{\mathrm{x}}$ [83]) when compared with the electron-selective metal oxide layers in c-Si solar cells. In the former case, the carrier transport through the oxide is argued to be defectassisted and does not rely on tunneling effects that may come into play for the ultrathin layers that are used in electron-selective contacts for c-Si solar cells. Furthermore, in the latter case, surface passivation is critical and strongly depends on the $\mathrm{TiO}_{\mathrm{x}}$ layer thickness [89], [90].
}

recently been reported that thermal $\mathrm{ALD} \mathrm{TiO}_{\mathrm{x}}$ and plasma ALD $\mathrm{TiO}_{\mathrm{x}}$ result in opposite types of band bending in c-Si, possibly due to the different deposition chemistry that influences the formation of the $\mathrm{TiO}_{\mathrm{x}} / \mathrm{c}-\mathrm{Si}$ interface. This suggests that the electron selectivity of $\mathrm{TiO}_{\mathrm{x}}$ can be strongly affected by the process that is used to grow the film [92]. The best solar cell results in which this material is used as an electron-selective contact have been achieved with thermal ALD $\mathrm{TiO}_{\mathrm{x}}$ as a full-area rear contact layer capped by $\mathrm{Al}$ [89]-[91]. It is likely that the electron selectivity is induced by chemical interactions between $\mathrm{TiO}_{\mathrm{x}}$ and $\mathrm{Al}$ after annealing. More specifically, it has been reported that a post-deposition annealing treatment resulted in the extraction of oxygen atoms from $\mathrm{TiO}_{\mathrm{x}}$ toward $\mathrm{Al}$, which could explain the observed $\rho_{\text {contact }}$ decrease by one order of magnitude [90]. Therefore, chemical interactions between $\mathrm{TiO}_{\mathrm{x}}$ and an adjacent metal layer, as well as a low WF value of the metal that is in contact with the $\mathrm{TiO}_{\mathrm{x}}$ layer, can be beneficial for the electron selectivity, while the presence of charge in the $\mathrm{TiO}_{\mathrm{x}}$ appears to play a relatively smaller role in this respect.

The excellent surface passivation of ALD $\mathrm{TiO}_{\mathrm{x}}$ has enabled a solar cell conversion efficiency of $20.5 \%$ when using $\mathrm{TiO}_{\mathrm{x}}$ as a passivating ARC [87] and even 21.6-22.1\% when using 3-3.5-nm $\mathrm{TiO}_{\mathrm{x}}$ as a full-area electron-selective rear contact in an $n$-type-based c-Si solar cell with an $\mathrm{Al}_{2} \mathrm{O}_{3} / \mathrm{SiN}_{\mathrm{x}}$-passivated diffused $p^{+}$emitter on the front side [89], [90], [93]. When aiming to benefit more from the transparency of $\mathrm{TiO}_{\mathrm{x}}$ and, thus, potentially achieve a higher solar cell conversion efficiency, it appears attractive to use $\mathrm{TiO}_{\mathrm{x}}$ as a front electron-selective contact layer. However, this would likely require the use of an additional front TCO with a suitable WF on top of the $\mathrm{TiO}_{\mathrm{x}}$ layer, which has, so far, not been demonstrated in a solar cell. Thermal stability is another concern. It appears that the formation of the crystalline phase of $\mathrm{TiO}_{\mathrm{x}}$ should be avoided during both the growth of the film and any post-deposition annealing treatments to preserve the passivation quality, irrespective of the used ALD Ti precursor [87], [88]. Such crystallization can occur already above $300^{\circ} \mathrm{C}$ [88], which may be an issue for device integration. Nevertheless, given the promising passivation quality and solar cell conversion efficiency results so far, an ultrathin $\mathrm{TiO}_{\mathrm{x}}$ layer could prove to be useful in the development of highefficiency c-Si solar cells, especially if it could be manufactured by a high-throughput method such as spatial ALD, PECVD, or atmospheric pressure chemical vapor deposition.

An example of a transition metal oxide that has been successfully employed to create a transparent passivating hole contact is (slightly) substoichiometric molybdenum oxide $\left(\mathrm{MoO}_{\mathrm{x}} ; x \approx 3\right)$ [94]-[100]. $\mathrm{MoO}_{\mathrm{x}}$ is known for its use as hole transport material in both organic PVs and perovskite solar cells [84], [85]. For $\mathrm{c}-\mathrm{Si}, \mathrm{MoO}_{\mathrm{x}}$ can mainly provide selectivity toward holes through its high WF $(>5.5 \mathrm{eV})$ in combination with its wide bandgap, which induces an accumulation of holes at the silicon surface. Based on these properties, $\mathrm{MoO}_{\mathrm{x}}$ can be considered as part of a family of materials together with $\mathrm{WO}_{\mathrm{x}}$ [97], [98], [101], [102], and vanadium oxide $\left(\mathrm{VO}_{\mathrm{x}}\right)$ [97], [98], [103]. These metal oxides have been used on the front side of a classical SHJ solar cell to replace the $p$-type a-Si:H layer [94], [97], [99], [101], [102], [104] or to improve the contact between the $p$-type a-Si:H layer and the TCO [102], [103], [105]. This way, a combination is cre- 
ated of the carrier-selective contact concepts shown in Fig. 1(b) and (c), i.e., a passivating layer such as a-Si:H together with a wide-bandgap semiconductor that has a very high WF.

For example, Battaglia et al. have used thermally evaporated $\mathrm{MoO}_{\mathrm{x}}$ in a standard SHJ solar cell device to replace the $p$-type a$\mathrm{Si}: H$ layer resulting in a substantial enhancement in photocurrent of $1.9 \mathrm{~mA} / \mathrm{cm}^{2}$ due to the higher transparency of $\mathrm{MoO}_{\mathrm{x}} \mathrm{com}-$ pared with $p$-type a-Si:H [106]. More recently, Geissbühler et al. demonstrated a SHJ solar cell with an evaporated $\mathrm{MoO}_{\mathrm{x}}$ hole collector with an impressive conversion efficiency of $22.5 \%$, mainly due to a reduced voltage loss with respect to the earlier results of Battaglia et al. [96]. In both cases, an intrinsic a-Si:H layer was present between the $\mathrm{MoO}_{\mathrm{x}}$ layer and the c$\mathrm{Si}$ wafer to ensure good chemical passivation and a high $V_{\text {oc }}$. Additionally, to further reduce the absorption losses, a SHJ solar cell yielding a conversion efficiency of $19.4 \%$ with holeand electron-selective contacts based on $\mathrm{MoO}_{\mathrm{x}}$ and lithium fluoride $(\mathrm{LiF})$, respectively, has been reported, such that the use of doped a-Si:H is avoided altogether [106]. The contact performance of thermally evaporated $\mathrm{MoO}_{\mathrm{x}}$ without an intrinsic a-Si:H interlayer was explored in detail by Bullock et al. for both $p$-type and $n$-type c-Si substrates, yielding rather low values for $\rho_{\text {contact }}\left(0.2-30 \mathrm{~m} \Omega \cdot \mathrm{cm}^{2}\right)$, but still fairly high values for $J_{0}$ (200-300 fA $\left./ \mathrm{cm}^{2}\right)$ [99]. Furthermore, evaporated local rear $\mathrm{MoO}_{\mathrm{x}}$ contacts embedded in an $\mathrm{Al}_{2} \mathrm{O}_{3} / \mathrm{SiN}_{\mathrm{x}}$ passivation stack have been used in a $p$-type solar cell, which has shown an efficiency of $20.4 \%$ [107].

All of the results just mentioned were achieved using thermally evaporated $\mathrm{MoO}_{\mathrm{x}}$. Low-temperature ALD of $\mathrm{MoO}_{\mathrm{x}}$ has also been demonstrated and is particularly promising for applications in SHJ solar cells due to its scalability and lowtemperature processing compatibility with a-Si:H passivation layers [95], [108]. However, so far, evaporated $\mathrm{MoO}_{\mathrm{x}}$ has been shown to yield a larger amount of band bending than ALD MoO and thus an enhanced hole selectivity [109], [110]. It should also be noted that, irrespective of the $\mathrm{MoO}_{\mathrm{x}}$ deposition method, an interlayer such as a-Si:H is still needed between $\mathrm{MoO}_{\mathrm{x}}$ and c-Si for good surface passivation. Furthermore, the WF value can be significantly lowered by the presence of oxygen vacancies, as has been demonstrated for tungsten oxide $\left(\mathrm{WO}_{\mathrm{x}}\right)$ [101], [104], [111], which also owes its hole selectivity to a high WF value, similar to $\mathrm{MoO}_{\mathrm{x}}$. However, the demonstrated high conversion efficiencies clearly underline the promising potential of $\mathrm{MoO}_{\mathrm{x}}$ in high-efficiency SHJ solar cells and hybrid combinations of solar cell structures, in which advantages in terms of transparency and simple manufacturing are combined, can be devised as well [12], [17].

In addition to metal oxides with relatively low bulk conductivity, such as $\mathrm{TiO}_{\mathrm{x}}, \mathrm{MoO}_{\mathrm{x}}, \mathrm{VO}_{\mathrm{x}}$, and $\mathrm{WO}_{\mathrm{x}}$, also materials that are traditionally considered as TCOs can be used to achieve carrier selectivity. Already in the 1960s, a heterojunction of conductive tin oxide $\left(\mathrm{SnO}_{2}\right)$ with c-Si was explored to form a rudimentary solar cell [112]. Although the idea of using a $\mathrm{TCO}$ as a carrier-selective layer in a c-Si solar cell is thus not new, zinc oxide ( $\mathrm{ZnO}), \mathrm{SnO}_{2}$, and tin-doped indium oxide (ITO) have only recently been explicitly explored as electron-selective contact materials in the context of high-efficiency c-Si solar cells by researchers such as Stradins and Young and co-workers
[29], [113]. These TCOs were prepared by sputter deposition on thermally grown $\mathrm{SiO}_{2}$ interlayers. The best passivating contact properties were found for ITO, which was sputtered on a relatively thick (4.5-nm) $\mathrm{SiO}_{2}$ layer, followed by a forming gas annealing treatment [29]. This resulted in a low $\rho_{\text {contact }}$ value $\left(11.5 \mathrm{~m} \Omega \cdot \mathrm{cm}^{2}\right)$, but yielded a relatively high $J_{0}\left(92.5 \mathrm{fA} / \mathrm{cm}^{2}\right)$, which was attributed to a relatively poor level of surface passivation [113]. However, this type of contact has not yet been tested in a solar cell. Wang et al. fabricated a SHJ solar cell, which uses boron-doped $\mathrm{ZnO}$ as full-area rear electron-selective layer. The doped $\mathrm{ZnO}$ outperformed $n$-type a-Si:H in the tested solar cell configuration, especially due to gains in $J_{\mathrm{sc}}\left(2 \mathrm{~mA} / \mathrm{cm}^{2}\right)$ and $F F(5 \%)$. This is largely due to an improved long-wavelength response caused by a lower refractive index and a higher conductivity resulting in a reduced series resistance, respectively [114]. Interestingly, it has recently been reported by Van de Loo that conductive and extrinsically doped $\mathrm{ZnO}$ films prepared by ALD can, in fact, provide outstanding surface passivation to both $n$ - and $p$-type c-Si with $J_{0}<7 \mathrm{fA} / \mathrm{cm}^{2}$ when, in analogy to passivating contacts based on poly-Si, it is deposited on a thin $\mathrm{SiO}_{2}$ layer and hydrogenated by $\mathrm{Al}_{2} \mathrm{O}_{3}$ [115]. Even though no $\rho_{\text {contact }}$ values have been reported yet, the fact that $\mathrm{ZnO}$ can provide surface passivation makes it of interest as passivating electron-selective contact material, thereby avoiding the use of an a-Si:H interlayer. Note that a passivating contact based on a TCO could provide sufficient conduction to serve as a lateral transport layer in a solar cell while simultaneously functioning as an ARC. This could enable a reduced solar cell processing complexity.

Another conceptually interesting approach is to make a carrier-selective tunneling contact for either electrons or holes by using a high fixed charge density in the tunnel oxide. For instance, a hole-selective tunneling contact has been devised by placing an ultrathin $\left(<2 \mathrm{~nm}\right.$ ) layer of $\mathrm{Al}_{2} \mathrm{O}_{3}$ (which is known for its surface passivating properties, large bandgap, and large negative fixed charge density $\left(-Q_{f}\right)[116]$, [117]) between $n$-Si and an aluminum doped zinc oxide ( $\mathrm{ZnO}: \mathrm{Al}$ ) film, following the approach of Fig. 1(e). The high negative $Q_{f}$ of $\mathrm{Al}_{2} \mathrm{O}_{3}$ induces some selectivity toward holes near the $\mathrm{Si} / \mathrm{Al}_{2} \mathrm{O}_{3}$ interface, while ideally the $\mathrm{ZnO}$ conduction band lines up with the c-Si valence band to enable tunnel recombination [27]. Although this early attempt to use metal oxides as part of a passivating contact leads to a decent passivation $\left(S_{\text {eff, } \max }=20 \mathrm{~cm} / \mathrm{s}\right)$ when used together with a very thin $(\sim 3 \mathrm{~nm})$ a-Si:H interlayer, the lowest reported contact resistivity for this layer stack is still rather high at 1.5$5 \Omega \cdot \mathrm{cm}^{2}$. This makes its application as a passivating contact challenging [25]. Yet, tunnel contacts that rely to a large extent on a sufficiently high fixed charge density for their carrier selectivity have only been marginally investigated so far and may deserve further attention.

Finally, when further exploring transition metal oxides in the context of passivating contacts, a lot can be learned from other fields, such as microelectronics and organic electronics, where the electrical properties of transition metal oxides have already been explored. It is likely that this class of materials will attract more attention in research when more examples of promising oxides can be identified and optimized. An example of such a material is hafnium oxide $\left(\mathrm{HfO}_{\mathrm{x}}\right)$, for which the c- 
Si passivation quality has recently been reported [118], [119]. Furthermore, tantalum oxide $\left(\mathrm{TaO}_{\mathrm{x}}\right)$ has recently appeared as a candidate electron-selective passivating material [120], while hole-selective contact properties have been demonstrated for nitrogen-doped copper oxide $\left(\mathrm{CuO}_{\mathrm{x}}: \mathrm{N}\right)$ [121]. However, so far, these metal oxides have not been integrated into a passivating contact structure, implying that their potential is not clear yet.

\section{Organics}

Besides the numerous inorganic materials that have so far been discussed, organic materials can also be used to form a carrier-selective contact structure with c-Si. Many of these materials were originally developed for use in organic PV devices. An early attempt from the 1990s involving iodinedoped poly- $\left(\mathrm{CH}_{3}\right)_{3} \mathrm{Si}$-cyclooctatetraene in combination with $n$ $\mathrm{Si}$ yielded a crude solar cell with a conversion efficiency approaching 5\% [122]. More recently, polythiophenes have been specifically investigated as candidate hole-selective materials for c-Si solar cells. Promising results have been obtained with poly(3-hexylthiophene) [123] and even more so with poly(3,4ethylenedioxythiophene) polystyrene sulfonate (PEDOT:PSS) [38], [39], [124]-[127]. PEDOT:PSS has been used as a contact layer on the front side [38], [39], [126] and the rear side [124], [125], [127] of a c-Si solar cell, both in a homojunction configuration with a diffused emitter [124], [125], [127] and a heterojunction structure involving a-Si:H [126], [127] or $\mathrm{TiO}_{\mathrm{x}}$ [39] layers. Note that the PEDOT:PSS layer was in all cases applied as a full-area contact layer on a non-textured surface. The hole selectivity of the PEDOT:PSS contact is induced by the slightly negative valence band offset and larger positive conduction band offset with respect to c-Si (see Fig. 2), combined with the fact that the WF of PEDOT:PSS is rather high $(\sim 5 \mathrm{eV})$ [38], [126]. Note that the selectivity mechanism is analogous to the electron-selective contact structure shown in Fig. 1(c). Using PEDOT:PSS on the rear side of the solar cell has so far proven to be more successful in terms of the device performance, yielding an impressive conversion efficiency of 20.6\% [125], [127]. The optimal contact performance that has been reported for PEDOT:PSS (with ultrathin $\mathrm{SiO}_{\mathrm{x}}$ as interlayer) can be expressed as $J_{0}=46 \mathrm{fA} / \mathrm{cm}^{2}$ together with $\rho_{\text {conctact }}=0.1 \Omega \cdot \mathrm{cm}^{2}[125]$.

Although the demonstrated contact performance and solar cell efficiency clearly illustrate that PEDOT:PSS is an interesting passivating contact material, process integration may be an issue due to the relatively poor thermal stability of this material and organics in general. It also remains a challenge to fabricate such a layer on a textured surface due to the spin-coating method that is commonly used to deposit the material. Furthermore, the absorption and reflection losses associated with this material make it difficult to effectively use it on the front side of a solar cell without compromising the short-circuit current density $\left(J_{\text {sc }}\right)$ and, thus, the conversion efficiency of the solar cell [126]. Finally, it is not yet clear whether organic electron-selective contact materials can be successfully incorporated into c-Si solar cells as well. The naphthalene-bis(dicarboximide)-based polymer P(NDI2OD-T2) has been suggested as a candidate electronselective material [126]. Its conduction band offset with c-Si is less than $0.1 \mathrm{eV}$, while it has a relatively high mobility $(0.45-$ $0.85 \mathrm{~cm}^{2} \cdot \mathrm{V}^{-1} \cdot \mathrm{s}^{-1}$ ) and a bandgap of $\sim 1.45 \mathrm{eV}$ that should induce a valence band offset of $\sim 0.3 \mathrm{eV}$ [127], [128], but this material has not yet been tested in a c-Si solar cell.

\section{Alkali/Alkaline Metals, Oxides, and Salts}

A relative newcomer in the field of passivating contact materials for c-Si solar cells is formed by the alkali/alkaline metals, salts, and oxides comprising a group 1 or 2 metal cation, which can be bonded in the form of carbonates [129], acetates [130] or fluorides [130]-[132]. In the field of organic electronics, and electroluminescent devices in particular, this class of materials has already been well known since their introduction as electrical contacts about two decades ago [131], but it has not yet been thoroughly explored in the context of c-Si solar cells. So far, the focus in c-Si passivating contact materials research in this area has been on evaluating the contact resistivity of various materials that can be deposited via thermal evaporation and testing the performance of the contact in both homo- and heterojunction solar cells. Examples include magnesium oxide $\left(\mathrm{MgO}_{\mathrm{x}}\right)$ [133], magnesium fluoride $\left(\mathrm{MgF}_{\mathrm{x}}\right)$ [134], $\mathrm{LiF}$ (as a local rear contact in a homojunction solar cell [135] or as a full-area rear contact combined with $i$-type a-Si:H in a SHJ solar cell [104]), potassium fluoride $\left(\mathrm{KF}_{\mathrm{x}}\right)$ [15], cesium fluoride $\left(\mathrm{CsF}_{\mathrm{x}}\right)$ [15], magnesium $(\mathrm{Mg})$ [136], and calcium (Ca) (as a local rear contact in a homojunction solar cell [137] or in combination with a passivating $\mathrm{TiO}_{\mathrm{x}}$ interlayer [138]). A more extensive list of contact resistivity values of similar materials can be found elsewhere [15].

All contact materials in this specific category reported so far are candidate electron-selective contacts. In the case of $\mathrm{MgO}_{\mathrm{x}}$, the working mechanism of the contact is assumed to rely on the combination of a high bulk conductivity and high electron concentration together with the passivation of gap states between $\mathrm{Al}$ and c-Si [133]. The other materials have a considerably lower WF than $\mathrm{Al}$, which is the property to which the Ohmic behavior and associated electron-selective contact properties are ascribed [16], [106], [134]-[137]. Respectable solar cell efficiencies of 19-20\% have so far been accomplished when employing these materials in homojunction [133]-[137] or heterojunction [106] solar cells involving full-area [106], [133], [134], [136] or local [135], [137] contacts. Although the reported performances of the different solar cell structures are promising and offer new routes toward high-efficiency solar cells, they do not yet match the quality of state-of-the-art homojunction or heterojunction solar cells. Since moderately low to very low contact resistivity values with c-Si have already been reported for the above-mentioned materials $\left(0.2-76 \mathrm{~m} \Omega \cdot \mathrm{cm}^{2}\right.$ [15], [106], [133]-[137]), while just a single report of a low $J_{0}$ value has appeared, it is likely that $J_{0}$ is generally more of a limiting factor in the solar cell performance than $\rho_{\text {contact }}$ for these materials. Hereby, it should be noted that the single reported low $J_{0}$ value $\left(10 \mathrm{fA} / \mathrm{cm}^{2}\right.$ [134]) depended on the use of an a-Si:H interlayer. This would explain why most of the above-mentioned solar cell structures employ either a-Si:H passivating layers [106], [134], [136] or local contacts [135], [137], since both these approaches are standard ways to reduce recombination losses. Nevertheless, there is still ample room to improve the quality of passivating contacts based on alkali/alkaline metals, oxides, and salts, for instance, by enhancing the passivating quality through interface treatments of the c-Si surface or via the exploration of other deposition techniques than thermal evaporation. 


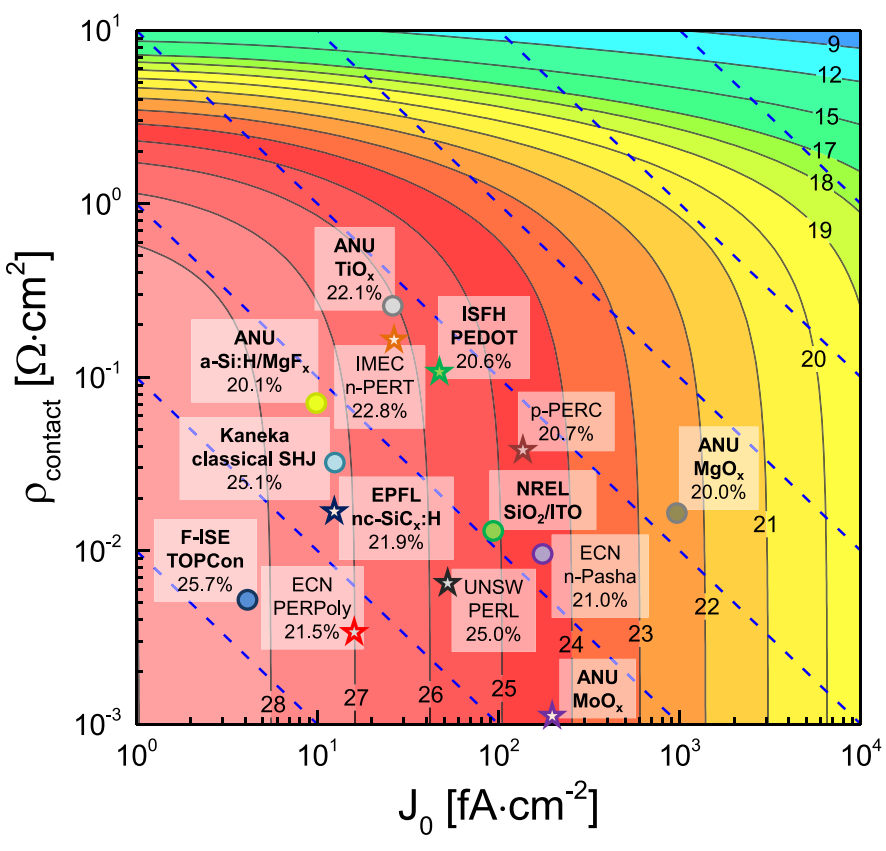

Fig. 3. Contour plot of the maximum c-Si solar cell efficiency as a function of $J_{0}$ and $\rho_{\text {contact }}$ as obtained from Quokka simulations [139]. A comparison of the electrical performance of various c-Si solar cell concepts is made in terms of the weighted area-corrected recombination parameter $J_{0}$ and the contact resistivity $\rho_{\text {contact }}$ for the rear side of the solar cell [7], [10], [11], [80], [89], [90], [93], [113], [125], [134], [140]-[144]. When the data are available, the reported record conversion efficiency value is shown next to the label for each solar cell architecture. Data points for full-area contacts are denoted in bold. Additionally, electron-selective contacts are marked with a circle, whereas holeselective contacts have star-shaped symbols. The blue-dashed lines represent isolines of constant $J_{0} \cdot \rho_{\text {contact }}$. Note that in the case of $\mathrm{TiO}_{\mathrm{x}}$, the reported values of $J_{0}$ and $\rho_{\text {contact }}$ correspond to a cell efficiency of $20.5 \%$ [89], but the $\rho_{\text {contact }}$ value for this contact structure has meanwhile been improved to $20 \mathrm{~m} \Omega \cdot \mathrm{cm}^{2}$ [90], while the champion cell efficiency has now reached $22.1 \%$ [93].

\section{COMPARISON OF PASSIVATING CONTACTS}

\section{A. Electrical Properties of Passivating Contacts}

As discussed in Section II, the effectiveness of a passivating contact can be described by its $J_{0}$ and $\rho_{\text {contact }}$ values, which together describe how carrier-selective it is. This means that different passivating contact structures can be directly compared by using these two parameters. The influence of $J_{0}$ and $\rho_{\text {contact }}$ on the maximum attainable cell efficiency has been visualized in Fig. 3. The iso-efficiency lines have been obtained from a device simulation using Quokka [139]. In the simulation, radiative and Auger recombination [145] are accounted for, and we assumed a uniform generation profile, an external series and shunt resistivity of 0 and $10^{6} \Omega \cdot \mathrm{cm}^{2}$, respectively, and an $n$-type wafer with a bulk resistivity of $10^{6} \Omega \cdot \mathrm{cm}$ to approximate an intrinsic c-Si wafer. ${ }^{3}$ Furthermore, an ideal front side is assumed, i.e., $J_{0}=0 \mathrm{fA} / \mathrm{cm}^{2}$ and $\rho_{\text {contact }}=0 \Omega \cdot \mathrm{cm}^{2}$, such that the effects

\footnotetext{
${ }^{3}$ When a more usual wafer resistivity of $3 \Omega \cdot \mathrm{cm}$ is assumed instead of the quasi-intrinsic bulk that we assumed here, a shift in the iso-efficiency lines towards the top right corner of Fig. 3 is observed. Consequently, the theoretical maximum conversion efficiencies of, e.g., the classical SHJ solar cell by Kaneka and the TOPCon solar cell of Fraunhofer ISE are lowered by $0.06 \%$ and $0.08 \%$ absolute, respectively. This implies that a more usual base doping level instead of the quasi-intrinsic wafer that is assumed to calculate the iso-efficiency lines shown in Fig. 3 accounts only for a limited part of the difference between the theoretical and practical efficiency limit.
}

of a full-area rear passivating contact can be visualized. Following Richter et al. [2], we assumed a $110-\mu \mathrm{m}$-thick wafer and a generation current density of $43.31 \mathrm{~mA} / \mathrm{cm}^{2}$. For such an idealized absorber, the calculated efficiency is thus solely limited by $J_{0}$ and $\rho_{\text {contact }}$ of the rear contact together with the unavoidable loss mechanisms in c-Si. Note that Auger recombination is not included in a roughly comparable analytical approach that has recently been used to calculate iso-efficiency lines in a $J_{0}-\rho_{\text {contact }}$ plot [113] and that our approach is comparable to other recent work [106], [107], [146], [147].

The $J_{0}-\rho_{\text {contact }}$ plot reveals that both parameters have a profound influence on the maximum attainable conversion efficiency of c-Si solar cells, although their influence is markedly different. The efficiency is rather insensitive to $\rho_{\text {contact }}$ values when they are below $\sim 100 \mathrm{~m} \Omega \cdot \mathrm{cm}^{2}$, whereas a strong reduction in cell efficiency is observed for higher values. This can be understood from the fact that at the maximum power point, a current close to the $J_{\mathrm{sc}}$ will flow through the contacts. Since this is a current density on the order of $\sim 40 \mathrm{~mA} / \mathrm{cm}^{2}$, the voltage loss over the contact due to the contact resistance gets into the $10 \mathrm{mV}$ range for $\rho_{\text {contact }}$ values exceeding $\sim 250 \mathrm{~m} \Omega \cdot \mathrm{cm}^{2}$, and this loss becomes non-negligible compared with the $V_{\text {oc }}$. In addition, at very low $\rho_{\text {contact }}$ values, it can be seen that the isoefficiency lines are approximately vertical and equally spaced in terms of $J_{0}$. This can be understood from the well-known inverse logarithmic dependence of $V_{\text {oc }}$ on $J_{0}$. For very low $J_{0}$ values, the spacing between the vertical iso-efficiency lines increases, which is mostly due to the fact that $V_{\mathrm{oc}}$ becomes limited by unavoidable bulk recombination in the silicon rather than by surface recombination. For example, in a $25.1 \%$ efficient c-Si solar cell, the contribution from the bulk has been estimated to be $8 \mathrm{fA} / \mathrm{cm}^{2}$ [7].

As was already discussed in the introduction, the formation of local contacts can be used to trade off $J_{0}$ and $\rho_{\text {contact }}$ and to enhance the solar cell conversion efficiency, albeit at the cost of additional processing complexity. Using this approach, the $J_{0}$ and $\rho_{\text {contact }}$ values become the weighted averages over the contacted and non-contacted areas, i.e., $J_{0}=A_{\mathrm{f}} \cdot J_{0, \text { metallized }}+\left(1-A_{\mathrm{f}}\right) \cdot J_{0, \text { passivated }}$ and $\rho_{\text {contact }}=\rho_{\text {contact,metallized }} / A_{\mathrm{f}}$, where $A_{\mathrm{f}}$ is the metallized area fraction of the solar cell. Therefore, assuming that an idealized perfectly passivating layer (i.e., $J_{0 \text {,passivated }}=0 \mathrm{fA} / \mathrm{cm}^{2}$ ) is used on the non-contacted areas, one can directly interchange $J_{0}$ and $\rho_{\text {contact }}$ by varying the contact fraction $A_{\mathrm{f}}$, i.e., $J_{0} \cdot \rho_{\text {contact }}$ $=$ constant. This is visualized by the dashed blue diagonal lines in Fig. 3, which are isolines of constant $J_{0} \cdot \rho_{\text {contact }}$. In other words, when a full-area contact features certain $J_{0}$ and $\rho_{\text {contact }}$ values, one can, in principle, move toward the upper left part of the plot along the blue diagonal lines by reducing the contact area fraction $A_{\mathrm{f}}$. Note, however, that such a move along the blue diagonal lines is possible only in this idealized simulation, while in reality additional tradeoffs such as lateral transport losses also need to be considered when moving from full-area to local contacts.

The main point of Fig. 3 is to compare the efficiency potential of different contact structures, i.e., when they are not limited by other aspects of the solar cell design. Note that when certain known $J_{0}$ and $\rho_{\text {contact }}$ contributions for the front side of the solar cell are to be included, they can as a first-order approximation 
be added to the $J_{0}$ and $\rho_{\text {contact }}$ values shown in Fig. 3 ; therefore, the maximum attainable efficiency can be estimated more precisely. However, this calculation is not done here. In order to make a comparison between various cell concepts based on their electrical properties, it is useful to assess different industrial and non-industrial solar cell structures based on the $J_{0}$ and $\rho_{\text {contact }}$ values corresponding to the rear side of the solar cell. This is useful because these values represent electrical losses that are present in all c-Si solar cells.

The $J_{0}$ and $\rho_{\text {contact }}$ values of various cell concepts are shown in Fig. 3 after having made corrections for the differences in contact area. Therefore, literature values have been converted to an equivalent full-area contact, i.e., the $J_{0}$ values in Fig. 3 are areaweighted averages of the $J_{0 \text {,passivated }}$ and $J_{0 \text {,metallized values. }}$ These corrected total $J_{0}$ and $\rho_{\text {contact }}$ values enable a comparison of various solar cell structures that have vastly different contact areas. Note that all the original values for $J_{0}, \rho_{\text {contact }}$, and the solar cell efficiency have been taken from literature [7], [10], [11], [80], [89], [90], [93], [113], [125], [134], [140]-[143], except for the Kaneka SHJ solar cell, the values for which have not been published, but were separately disclosed to us for the purpose of this work [144]. For the sake of simplicity, we only compare solar cell structures, which have contacts on both sides of the c-Si wafer.

While the conversion efficiencies enabled by the classical SHJ and oxide/poly-Si structures differ by less than $1 \%$ absolute, it is clear that both of these owe their excellent performance to similar very low $J_{0}$ values. At the same time, while the values for $\rho_{\text {contact }}$ of these structures are one order of magnitude apart-for this $\rho_{\text {contact }}$ range-this apparently has a smaller impact on the conversion efficiency than $J_{0}$. It is also clear that the PERL cell performs excellently in terms of $\rho_{\text {contact }}$, which indicates that the resistance at the c-Si/metal interface is very small, even for a very small contact fraction, i.e., $0.16 \%$. However, the same very small contacts still comprise the recombinative c-Si/metal interface, which poses a limit on the desired reduction of $J_{0}$, indicating that this type of solar cell cannot be improved much further, since it is not feasible-certainly not industrially-to reduce the contact fraction even further. Furthermore, when considering the relatively novel passivating contact materials shown in Fig. 3, it appears that the solar cells with contacts based on $\mathrm{TiO}_{\mathrm{x}}$ and PEDOT:PSS are limited in their conversion efficiency by both $J_{0}$ and $\rho_{\text {contact }}$, while the solar cell with a $\mathrm{MoO}_{\mathrm{x}}$ contact is predominantly limited by a relatively high $J_{0}$ value. Finally, regarding the examples of industrial solar cell types, e.g., the n-PERT, p-PERC, and n-Pasha solar cells, the striking difference between these is that the n-PERT cell has a much lower $J_{0}$ value, while the p-PERC cell and especially the $\mathrm{n}$-Pasha cell have a far lower $\rho_{\text {contact }}$ value. Since the n-PERT solar cell has a significantly higher conversion efficiency than the p-PERC and the n-Pasha solar cells, it appears again that lowering $J_{0}$ is generally more important than it is to achieve a low $\rho_{\text {contact }}$ when aiming at a further increase in cell efficiency. When considering the gap between the theoretical upper limit and the practically obtained values for the solar cell efficiency, it is interesting to see that the further potential for the PERL solar cell is, in fact, more limited than it is for the SHJ solar cell or a solar cell with an oxide/poly-Si contact. When combining the outcome of the calculated efficiencies with the current stateof-the-art values, it is clear that below the previously mentioned $\rho_{\text {contact }}$ value of $\sim 100 \mathrm{~m} \Omega \cdot \mathrm{cm}^{2}$ (when neglecting the electrical losses on the front side of the solar cell), no significant improvement in the solar cell efficiency should be expected when further reducing $\rho_{\text {contact }}$. Therefore, to fabricate a high-efficiency solar cell, it is apparently more important to further reduce $J_{0}$ than it is to lower $\rho_{\text {contact }}$ once a sufficiently low $\rho_{\text {contact }}$ value has been reached. These findings not only justify the increased research effort in the field of passivating contacts in recent times, but can also be helpful in future developments of passivating contacts when aiming to further reduce the gap between the demonstrated record c-Si cell efficiency and the theoretical limit.

\section{B. Optical Properties of Passivating Contacts}

Besides their electrical properties, a further key design requirement for materials in a passivating contact structure is to minimize the parasitic absorption losses. In solar cell designs that are fully rear-contacted, such as interdigitated back contact (IBC) structures, absorption losses play a smaller role due to the fact that the contact materials are placed on the rear side of the solar cell and the high bandgap of the materials that are typically used on the front side. However, the vast majority of industrial c-Si solar cells have contacts on both sides of the wafer. The reflection and absorption induced by the layers on the front side of the solar cell are normally minimized by using very wide bandgap materials to achieve combined antireflective and passivating properties, such as $\mathrm{SiN}_{\mathrm{x}}$ stacked on top of $\mathrm{Al}_{2} \mathrm{O}_{3}$ [156]. In the case of solar cells with a heterojunction front contact, additional layers must be present to provide charge carrier selectivity and lateral conduction, and it is imperative that absorption in these layers is minimized. Additionally, the absorption in the a-Si:H layers that are part of the typical SHJ solar cell design imposes limits on the maximum current that can be extracted from the solar cell [46], as illustrated in Fig. 4. Clearly, the absorption in a-Si:H is much larger than the absorption losses associated with alternative carrier-selective layers, such as $\mathrm{MoO}_{\mathrm{x}}$, and $\mathrm{TiO}_{\mathrm{x}}$, which illustrates the potential of these materials. It should be noted that the typical thickness of these materials ( $\sim 10 \mathrm{~nm}$ or less) is similar to that of the a-Si:H layers that are commonly used in classical SHJ solar cells, which enables a comparison based on the absorption coefficient $(\alpha)$ spectra, although the refractive index affects the absorption as well. For PEDOT:PSS and poly-Si, layer thicknesses of several tens of nanometers are however more typical, which underlines that it is difficult to use these materials on the front side of a solar cell.

To assess the impact of the absorption losses on the solar cell performance, OPAL2 simulations [155] were conducted on possible examples of front contact structures involving a selection of the carrier-selective contact materials shown in Fig. 4(a) and (b). To quantify the impact of the differences in absorption coefficient on the $J_{\mathrm{sc}}$ of a solar cell, the maximum attainable short-circuit current density $J_{\text {sc,max }}$ is shown in Fig. $4(\mathrm{c})$ as a function of the carrier-selective layer thickness. A randompyramid-textured wafer with a thickness of $110 \mu \mathrm{m}$ is assumed and an $i$-type a-Si:H [46] layer with a thickness of $5 \mathrm{~nm}$ is in- 

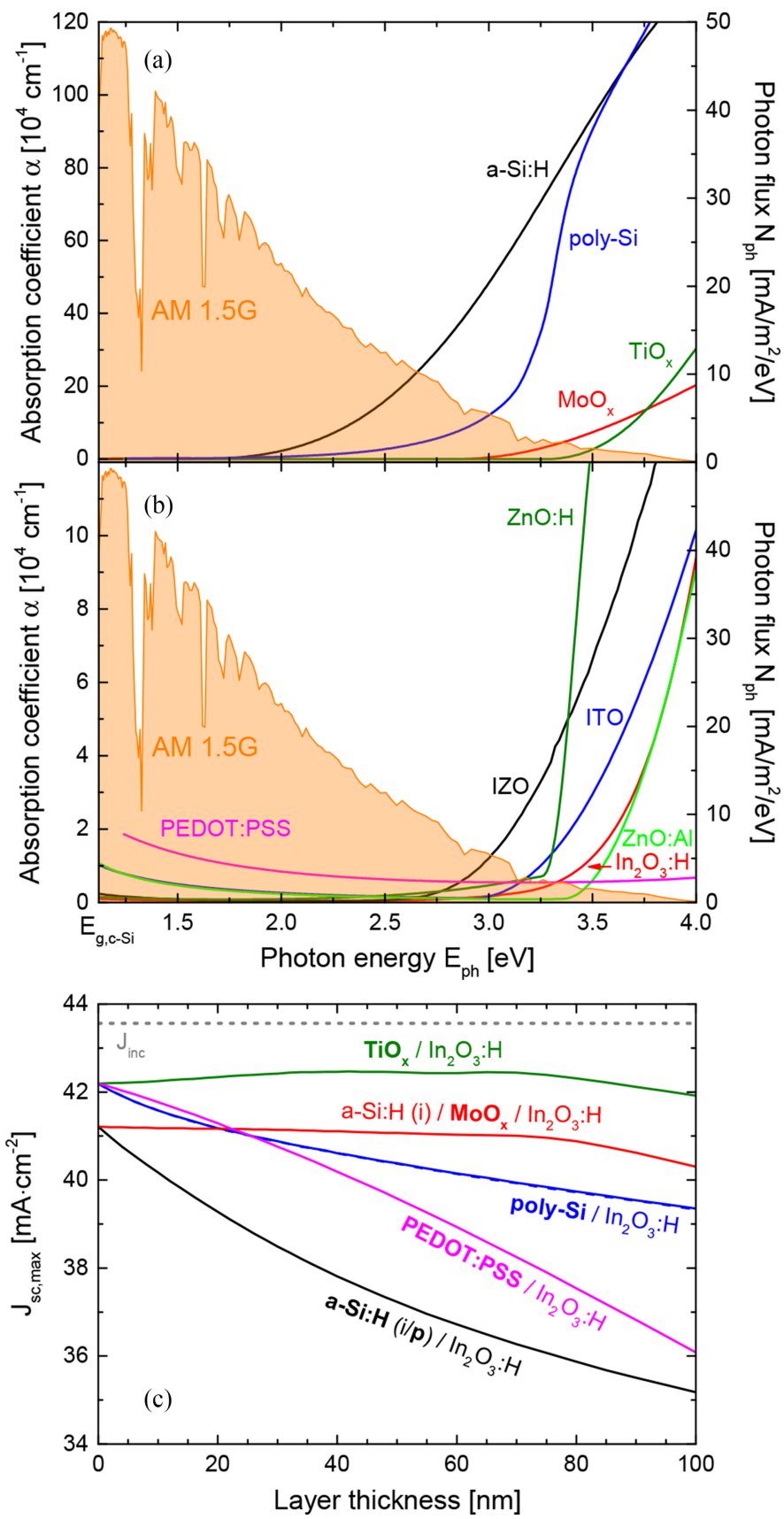

Fig. 4. Absorption coefficient $(\alpha)$ spectra for various (a) passivating and/or carrier-selective materials and (b) transparent conducting materials that can be used for lateral electrical transport in a solar cell. Note the difference in vertical axis scale for the top and bottom graphs. The AM1.5G solar spectrum is shown as a reference to illustrate in which parts of the spectrum the absorption losses induced by the materials present on the front side of the solar cell affect the generated photocurrent. The absorption data of the PEDOT:PSS layer were obtained from spectroscopic ellipsometry measurements on samples described elsewhere [148]. The same applies to the data for $\mathrm{MoO}_{\mathrm{x}}(x \approx 3)$ [95], $\mathrm{In}_{2} \mathrm{O}_{3}: \mathrm{H}$ [149], [150], ZnO:Al [151], ZnO:H [152], ITO [151], IZO [153], poly-Si [154], and a-Si:H [46]. (c) Using OPAL2 simulations [155], the maximum short-circuit current density $\left(J_{\mathrm{sc} \text { max }}\right)$ is evaluated as a function of the layer thickness for a variety of carrier-selective materials when used in a front contact structure. The poly-Si optical data needed for the simulation were obtained using a numerical approximation described elsewhere [71].

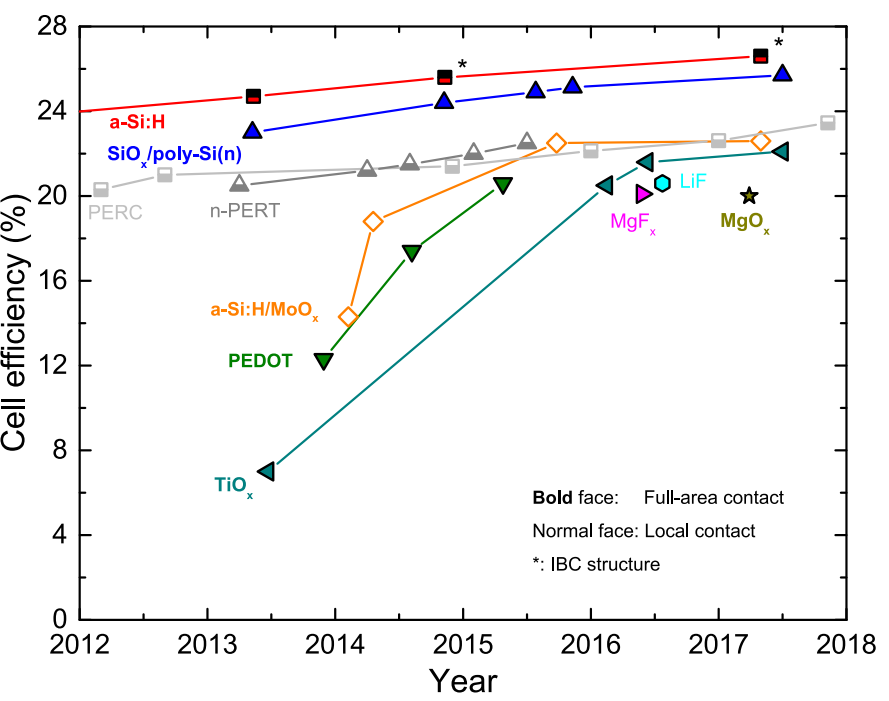

Fig. 5. Conversion efficiency of silicon solar cells incorporating various passivating contact structures. As reference, efficiencies of PERC and n-PERT homojunctions have been included [20], [141], [157]-[160]. Open symbols are used for cells comprising hole-selective contacts, whereas filled symbols are used for cells comprising electron-selective contact materials. Half-filled symbols are used for the reference homojunctions that include doped $\mathrm{Si}$ as carrier-selective structures.

serted between c-Si and the carrier-selective layer in the cases of $p$-type a-Si:H [46], i.e., the classical SHJ front contact, and $\mathrm{MoO}_{\mathrm{x}}$ [95], which both currently require this interlayer for surface passivation. In the case of $\mathrm{TiO}_{\mathrm{x}}$ [87], doped poly-Si (with a doping level of $10^{20} \mathrm{~cm}^{-3}$ ) [155], and PEDOT:PSS [148], such an a-Si:H interlayer is not included, as these materials already provide sufficient surface passivation. Note that the PEDOT:PSS thickness variation is also shown for a textured surface, although in practice the spin coating method is only compatible with planar surfaces. Crystalline hydrogenated indium oxide $\left(\operatorname{In}_{2} \mathrm{O}_{3}: \mathrm{H}\right)$ [149], [150] is used as a highly transparent front TCO and ARC to complete the front contact structure in the simulation such that the absorption losses of the carrier-selective layers can be well compared. Note that the $\operatorname{In}_{2} \mathrm{O}_{3}: \mathrm{H}$ layer thickness is optimized to maximize the $J_{\mathrm{sc}, \max }$ value for every carrier-selective layer thickness. Based on Fig. 4(c), it is clear that the $p$-type a-Si:H layer thickness in a classical SHJ solar cell is very critical and cannot be more than only a few nanometers without introducing significant $J_{\mathrm{sc}}$ losses. The same argument holds for doped poly-Si and PEDOT:PSS, which shows why these materials are typically used on the rear side of the solar cell. The high bandgap of $\mathrm{MoO}_{\mathrm{x}}$ and $\mathrm{TiO}_{\mathrm{x}}$ clearly enables a higher $J_{\mathrm{sc} \text {, max }}$. Especially for the case of $\mathrm{TiO}_{\mathrm{x}}$, where no a-Si:H interlayer is needed, $J_{\mathrm{sc} \text {,max }}$ is only approximately $1 \mathrm{~mA} / \mathrm{cm}^{2}$ lower than the incident photon current density $\left(J_{\text {inc }}\right)$ provided by the AM1.5G illumination. As was described earlier mostly in qualitative terms, these results illustrate the need for more transparent contact materials in a quantitative fashion.

\section{Status and Prospects of Passivating Contacts in SOLAR CELLS}

An overview of the conversion efficiency of reported c-Si solar cells containing passivating contacts is presented in Fig. 5. As discussed earlier, the use of passivating contacts has resulted 
in record-high conversion efficiencies for c-Si solar cells. Most prominently, a-Si:H and $\mathrm{SiO}_{\mathrm{x}} / n$-type poly-Si have resulted in solar cells with conversion efficiencies of $26.6 \%\left(180 \mathrm{~cm}^{2}\right)$ [5] and $25.7 \%\left(4 \mathrm{~cm}^{2}\right)[11]$, respectively, demonstrating the great potential of passivating contacts. Note that in these particular high-efficiency concepts, the passivating contacts are only used at the rear side of the cell to minimize parasitic absorption losses. Specifically, the a-Si:H-based record cell has an IBC configuration, whereas in the $\mathrm{SiO}_{\mathrm{x}} / n$-type poly-Si-based cell, a homojunction is used at the front side. To also allow for such high efficiencies with a passivating contact at the front side, research initiatives are targeting highly transparent passivating contact materials. Since 2013, an increasing variety of new materials are being explored for such transparent passivating contacts, resulting in significant progress in efficiencies for laboratory-scale devices incorporating such contacts. For instance, the efficiencies of solar cells incorporating contacts based on $\mathrm{MoO}_{\mathrm{x}}$ and $\mathrm{TiO}_{\mathrm{x}}$ are already almost on par with the conversion efficiencies for state-of-the-art PERC and n-PERT solar cells. Given the novelty of these transparent passivating contacts and the ongoing search for new or improved materials, even higher conversion efficiencies can be expected in the near future.

Although the proof of principle of these new passivating contact materials is thus clearly demonstrated, not all the manufacturing processes that are used in the abovementioned emerging solar cells are industrially viable. For instance, expensive or low-throughput methods such as photolithography, evaporation, and long drive-in steps are being used. Of the passivating contact concepts displayed in Fig. 5, only the cells incorporating a-Si:H-based contacts are known to be currently produced at industrial scale. Even though such solar cells can exhibit very high efficiencies, some distinct drawbacks of this type of cell are the use of PECVD equipment to deposit a-Si:H, which is not a part of typical industrial homojunction c-Si solar cell production lines, and the upper limit on the solar cell processing temperature of $\sim 200^{\circ} \mathrm{C}$. The latter makes a-Si:H incompatible with the high-temperature "firing" step $\left(\sim 800^{\circ} \mathrm{C}\right)$, which is conventionally used to contact homojunction cells. Consequently, silver paste that is compatible with low-temperature curing (instead of conventional fire-through metal paste) has to be used to form the metal contacts on these solar cells, which has been identified as a relatively large component of the module costs [161]. Due to these challenges, dedicated heterojunction production lines are needed and the market share of classical SHJ solar cells is still rather modest, although this has been projected to improve in the following years [162]. In contrast with a-Si:H-based passivating contacts, poly-Si can be compatible with conventional screen printing and firing processes [57] and could, therefore, be integrated in existing homojunction production lines in an evolutionary fashion. While $n$-type poly-Si is being explored as a candidate material to replace the phosphorus-doped Si region at the rear side of n-PERT cells [163], $p$-type poly-Si is of interest as passivating rear contact for mainstream $p$-Si cell architectures such as PERC or Al-BSF.

Ideally, processing of high-efficiency solar cells should be robust and cost-effective. In this respect, passivating contacts could bring some distinct advantages to solar cells and their man- ufacturing. For example, metal-oxide-based passivating contacts feature low absorption losses, which make them suitable for front-side application, and allow good full-area contacts with low recombination and resistive losses to be made to lightly doped c-Si surfaces. These layers can also be deposited selectively on one side of a wafer at relatively low temperatures, while being compatible with higher metallization temperatures than a-Si:H. Thus, a potential simple processing flow for a metal oxide passivating-contact-based cell concept might consist of wafer texturing/cleaning, single-sided deposition of electronand hole-selective layers (e.g., $\mathrm{TiO}_{\mathrm{x}}$ and $\mathrm{MoO}_{\mathrm{x}}$ ) on front and rear, and contacting/metallization using non-fire-through materials (possibly including deposition of a TCO layer for lateral carrier transport). This potentially permits the elimination of high-temperature diffusion, oxidation, and contact-firing steps (together with associated masking and etching), as well as steps involved in local contact formation. Thus, in principle, the equipment and processes required to form such a solar cell could allow for lean and low-temperature processing.

From the abovementioned envisaged solar cell process flow, it becomes clear that several solar cell integration aspects deserve more attention in future passivating contact research. For instance, most of the passivating contact results have, thus, far been obtained on mirror-polished Si (100) surfaces, whereas textured surfaces with (for monocrystalline $\mathrm{Si}$ ) (111)-oriented facets are generally used in solar cells to reduce reflectance losses.

Also, the contacting of the carrier-selective layer by a TCO or metal has to be addressed when considering solar cell integration. New TCOs are being explored in an attempt to reduce the absorption losses with respect to well-known materials such as $\mathrm{ZnO}$ :Al and ITO, which are typically deposited by sputtering or ALD. Examples include $\mathrm{In}_{2} \mathrm{O}_{3}: \mathrm{H}$, which is more transparent in the long-wavelength range in comparison with ITO due to a reduced FCA [149], [151], [164], [165], as well as indium zinc oxide (IZO) [153], and hydrogen-doped zinc oxide ( $\mathrm{ZnO}: \mathrm{H})$ [115], [152]. Note that doped ZnO can also be used as a transparent contact electrode [151], [165], although this comes at the expense of a higher FCA due to a reduced carrier mobility. However, when applied at the rear side of the solar cell, these drawbacks are essentially circumvented. Furthermore, as was mentioned in Section II, the contacting of a passivating contact material can affect the measured $J_{0}$ when the conductivity for minority carriers toward the metal is still sufficiently high. The application of a metal or TCO can itself also affect the selectivity of the passivating contact. In particular, for thin lightly doped passivating contacts, the WF of the metal or the TCO strongly affects the band bending in the c-Si, in turn affecting the field-effect passivation and the charge-carrier selectivity, as well as the contact resistivity [101], [102], [104], [109]. For instance, on the electron-collecting side of the solar cell, doped $\mathrm{ZnO}$ can be used more effectively than ITO due to the lower WF of $\mathrm{ZnO}$ [166]. Possible damage from TCO or metal deposition also needs to be considered. For instance, it is well known that sputter deposition, typically used to prepare TCOs, can reduce the passivation quality of a-Si:H due to plasma damage. To prevent such damage, soft deposition methods such as ALD have been explored for the deposition of TCOs on a-Si:H [151], [165], 
while the same approach can be followed for a TCO deposition on poly-Si [105].

Additionally, the fabrication of passivating contacts should preferably be compatible with high-volume manufacturing. In this respect, the use of low-cost materials and precursors, a wide process window, high-temperature stability, and highthroughput deposition methods is highly desirable. Finally, other important aspects that deserve more attention in future research on passivating contacts are their long-term stability against potential- and light-induced degradation, which are both prerequisites for commercial solar cells.

\section{CONCLUSION AND OUTLOOK}

To enhance the conversion efficiency of c-Si solar cells, it is becoming increasingly important to reduce the charge carrier recombination at the contacts. To this end, passivating contacts have become a focus of research. Ideally, a passivating contact is selectively conductive for either electrons or holes, while simultaneously passivating the c-Si surface. Materials that have been and are being considered for passivating contact applications include a-Si:H, poly-Si, transition metal oxides, organics, and alkali/alkaline metals, oxides, and salts. Poly-Si is particularly interesting due to the combination of excellent passivation and charge carrier selectivity with good thermal stability that it provides, while metal oxides are attractive for possible use on the front side of a solar cell because of their high transparency. The electrical losses that are induced by various passivating contact materials are compared in terms of two key figures of merit: $J_{0}$ and $\rho_{\text {contact }}$. Although the values of both these two parameters should be very low when aiming for solar cells with a high conversion efficiency, it appears that no significant efficiency gains should be expected once a sufficiently low $\rho_{\text {contact }}$ value has been reached, while reducing the $J_{0}$ value as much as possible does generally yield an improvement in the maximum attainable efficiency.

Despite the significant developments in the field of passivating contacts, especially over the last decade, many challenges remain for a successful integration of new passivating contact materials in solar cell manufacturing. More specifically, these emerging materials should be prepared in a cost-effective way, scalable to high-volume manufacturing, yield solar cells with a high conversion efficiency, and exhibit long-term stability. Finally, the contacting of novel passivating contact materials by metals or TCOs deserves more attention in future research. Nevertheless, the use of new passivating contact materials can potentially bring many advantages to solar cell manufacturing, such as a significantly simplified and a low-temperature fabrication process flow, ideally without local contacts, while enabling high solar cell conversion efficiencies.

\section{ACKNOWLEDGMENT}

The authors would like to gratefully acknowledge Dr. I. G. Romijn from the Energy Research Centre of the Netherlands (ECN) (The Netherlands), Dr. F. Duerinckx from imec (Belgium), and Dr. K. Nakano from Kaneka Corporation (Japan) for providing the latest values of $J_{0}$ and $\rho_{\text {contact }}$ for the rear side of the n-Pasha, n-PERT, and SHJ solar cells, respectively. Dr. G. J. M. Janssen from ECN (The Netherlands) is acknowl- edged for assistance with the Quokka simulations. Additionally, we acknowledge J. Palmans and M. F. J. Vos from Eindhoven University of Technology (Netherlands) for useful discussions.

\section{REFERENCES}

[1] Fraunhofer ISE: Photovolt. Report, 2017.

[2] A. Richter, M. Hermle, and S. W. Glunz, "Reassessment of the limiting efficiency for crystalline silicon solar cells," IEEE J. Photovolt., vol. 3, no. 4, pp. 1184-1191, Oct. 2013.

[3] K. Yoshikawa et al., "Silicon heterojunction solar cell with interdigitated back contacts for a photoconversion efficiency over 26\%," Nature Energy, vol. 2, 2017, Art. no. 17032.

[4] R. M. Swanson, "Approaching the $29 \%$ limit efficiency of silicon solar cells," in Proc. 31st IEEE Photovolt. Spec. Conf., Orlando, FL, USA, 2005, pp. 889-894.

[5] K. Yoshikawa et al., "Exceeding conversion efficiency of $26 \%$ by heterojunction interdigitated back contact solar cell with thin film Si technology," Sol. Energy Mater. Sol. Cells, vol. 173, pp. 37-42, 2017.

[6] M. Green, "The passivated emitter and rear cell (PERC): From conception to mass production," Sol. Energy Mater. Sol. Cells, vol. 143, pp. 190-197, 2015 .

[7] S.W. Glunz et al., "The irresistible charm of a simple current flow pattern $-25 \%$ with a solar cell featuring a full-area back contact," in Proc. 31 st Eur. Photovolt. Sol. Energy Conf., Hamburg, Germany, 2015, pp. 259263.

[8] K. Masuko et al. "Achievement of more than $25 \%$ conversion efficiency with crystalline silicon heterojunction solar cell," IEEE J. Photovolt., vol. 4, no. 6, pp. 1433-1435, Nov. 2014.

[9] D. D. Smith et al., "Toward the practical limits of silicon solar cells," IEEE J. Photovolt., vol. 4, no. 6, pp. 1465-1469, Nov. 2014.

[10] D. Adachi, J. L. Hernández, and K. Yamamoto, "Impact of carrier recombination on fill factor for large area heterojunction crystalline silicon solar cell with $25.1 \%$ efficiency," Appl. Phys. Lett., vol. 107, 2015, Art. no. 233506

[11] A. Richter et al., "n-Type Si solar cells with passivating electron contact: Identifying sources for efficiency limitations by wafer thickness and resistivity variation," Sol. Energy Mater. Sol. Cells, vol. 173, pp. 96-105, 2017.

[12] J. Melskens et al., "Concepts and prospects of passivating contacts for crystalline silicon solar cells," in Proc. 42nd IEEE Photovolt. Spec. Conf., New Orleans, LA, USA, 2015, pp. 1-6.

[13] A. Cuevas et al., "Skin care for healthy silicon solar cells," in Proc. 42nd IEEE Photovolt. Spec. Conf., New Orleans, LA, USA, 2015, pp. 1-6.

[14] C. Battaglia, A. Cuevas, and S. de Wolf, "High-efficiency crystalline silicon solar cells: Status and perspectives," Energy Environ. Sci., vol. 9, pp. 1552-1576, 2016.

[15] J. Bullock et al., "Survey of dopant-free carrier-selective contacts for silicon solar cells," in Proc. 43rd IEEE Photovolt. Spec. Conf., Portland, OR, USA, 2016, pp. 210-214.

[16] M. Hermle, Photovolt. Solar Energy: From Fundamentals to Applications, A. Reinders, P. Verlinden, and A. Freundlich, Eds. New York, NY, USA: Wiley, 2017, pp. 125-135.

[17] B. Macco, B. W. H. van de Loo, and W. M. M. Kessels, Atomic Layer Deposition in Energy Conversion Applications, J. Bachmann, Ed. New York, NY, USA: Wiley, 2017.

[18] P. Gao et al., "Dopant-free and carrier-selective heterocontacts for silicon solar cells: Recent advances and perspectives," Adv. Sci., 2017, Art. no. 1700547.

[19] U. Würfel, A. Cuevas, and P. Würfel, "Charge carrier separation in solar cells," IEEE J. Photovolt., vol. 5, no. 1, pp. 461-469, Jan. 2015.

[20] A. Cuevas and D. Yan, "Misconceptions and misnomers in solar cells," IEEE J. Photovolt., vol. 3, no. 2, pp. 916-923, Apr. 2013.

[21] Z. C. Holman, S. de Wolf, and C. Ballif, "Improving metal reflectors by suppressing surface plasmon polaritons: A priori calculation of the internal reflectance of a solar cell," Light: Sci. Appl. vol. 2, p. e106, 2013.

[22] D. L. Pulfrey, "MIS solar cells: A review," IEEE Trans. Electron Devices, vol. ED-25, no. 11, pp. 1308-1317, Nov. 1978.

[23] B. Macco, B. W. H. van de Loo, J. Melskens, S. Smit, and W. M. M Kessels, in Proc. 43rd IEEE Photovolt. Spec. Conf., Portland, OR, USA, 2016, pp. 2473-2478.

[24] J. A. del Alamo and R. M. Swanson, "The physics and modeling of heavily doped emitters," IEEE Trans. Electron Devices, vol. ED-31, no. 12 , pp. 1878-1888, Dec. 1984. 
[25] S. de Wolf, A. Descoeudres, Z. C. Holman, and C. Ballif, "Highefficiency silicon heterojunction solar cells: A review," Green, vol. 2, pp. 7-24, 2012.

[26] K. K. Ng and H. C. Card, "Asymmetry in the $\mathrm{SiO}_{2}$ tunneling barriers to electrons and holes," J. Appl. Phys., vol. 51, no. 4, pp. 2153-2157, 1980.

[27] S. Smit, D. Garcia-Alonso, S. Bordihn, M. S. Hanssen, and W. M. M. Kessels, "Metal-oxide-based hole-selective tunneling contacts for crystalline silicon solar cells," Sol. Energy Mater. Sol. Cells, vol. 120, pp. 376$382,2014$.

[28] J. Robertson, "Band offsets of wide-band-gap oxides and implications for future electronic devices," J. Vac. Sci. Technol. B, vol. 18, pp. 1785-1791, 2000.

[29] P. Stradins et al., "Passivated tunneling contacts to n-type wafer silicon and their implementation into high performance solar cells," in Proc. 6th World Conf. Photovolt. Energy Convers., Kyoto, Japan, 2014, pp. 1-4.

[30] M. T. Greiner et al., "Universal energy-level alignment of molecules on metal oxides," Nature Mater, vol. 11, pp. 76-81, 2011.

[31] J. Meyer et al., "Transition metal oxides for organic electronics: Energetics, device physics and applications," Adv. Mater, vol. 24, pp. 5408-5427, 2012.

[32] J. W. Keister et al., "Band offsets for ultrathin $\mathrm{SiO}_{2}$ and $\mathrm{Si}_{3} \mathrm{~N}_{4}$ films on $\mathrm{Si}(111)$ and $\mathrm{Si}(100)$ from photoemission spectroscopy," J. Vac. Sci. Technol. B., vol. 17, no. 4, pp. 1831-1835, 1999.

[33] R. Ludeke, M. T. Cuberes, and E. Cartier, "Local transport and trapping issues in $\mathrm{Al}_{2} \mathrm{O}_{3}$ gate oxide structures," Appl. Phys. Lett., vol. 76, no. 20, pp. 2886-2888, 2000.

[34] T.F. Schulze, L. Korte, F. Ruske, and B. Rech, "Band lineup in amorphous/crystalline silicon heterojunctions and the impact of hydrogen microstructure and topological disorder," Phys. Rev. B, vol. 83, 2011, Art. no. 165314.

[35] S. Avasthi et al., "Hole-blocking titanium-oxide/silicon heterojunction and its application to photovolt.," Appl. Phys. Lett., vol. 102, 2013, Art. no. 203901.

[36] D. Gebeyehu et al., "Hybrid solar cells based on dye-sensitized nanoporous $\mathrm{TiO}_{2}$ electrodes and conjugated polymers as hole transport materials," Synthetic Metals, vol. 125, pp. 279-287, 2002.

[37] M. D. Irwin, D. B. Buchholz, A. W. Hains, R. P. H. Chang, and T. J. Marks, "p-type semiconducting nickel oxide as an efficiency-enhancing anode interfacial layer in polymer bulk-heterojunction solar cells," Proc. Nat. Acad. Sci. USA, vol. 105, pp. 2783-2787, 2008.

[38] S. Jäckle et al., "Junction formation and current transport mechanisms in hybrid n-Si/PEDOT:PSS solar cells," Sci. Rep., vol. 5, 2015, Art. no. 13008.

[39] K. Nagamatsu et al., "Titanium dioxide/silicon hole-blocking selective contact to enable double-heterojunction crystalline silicon-based solar cell," Appl. Phys. Lett., vol. 106, 2015, Art. no. 123906.

[40] A. Klein et al., "Transparent conducting oxides for photovoltaics: Manipulation of Fermi level, work function and energy band alignment," Materials, vol. 3, pp. 4892-4914, 2010.

[41] R. L. Anderson, "Germanium-gallium arsenide heterojunctions," IBM J. Res. Develop., vol. 4, no. 3, pp. 283-287, 1960.

[42] J. Tersoff, "Theory of semiconductor heterojunctions: The role of quantum dipoles," Phys. Rev. B, vol. 30, no. 8, pp. 4874-4877, 1984.

[43] W. Mönch, Semiconductor Surfaces and Interfaces (Springer Series in Surface Sciences), 3rd ed., G. Ertl, R. Gomer, H. Lüth, and D. L. Mills, Eds. Berlin, Germany: Springer, 2001.

[44] M. Schaper, J. Schmidt, H. Plagwitz, and R. Brendel, " $20.1 \%$-efficient crystalline silicon solar cell with amorphous silicon rear-surface passivation," Prog. Photovolt., Res. Appl., vol. 13, pp. 381-386, 2005.

[45] A. Kanevce and W. K. Metzger, "The role of amorphous silicon and tunneling in heterojunction with intrinsic thin layer (HIT) solar cells," $J$. Appl. Phys., vol. 105, 2009, Art. no. 094507.

[46] Z. C. Holman et al., "Current losses at the front of silicon heterojunction solar cells," IEEE J. Photovolt., vol. 2, no. 1, pp. 7-15, Jan. 2012.

[47] B. Macco et al., "Correlating the silicon surface passivation to the nanostructure of low-temperature a-Si:H after rapid thermal annealing," $J$. Appl. Phys., vol. 122, 2017, Art. no. 035302.

[48] J. Melskens et al., "New insights in the nanostructure and defect states of hydrogenated amorphous silicon obtained by annealing," IEEE J. Photovolt., vol. 3, no. 1, pp. 65-71, Jan. 2013.

[49] S. de Wolf and M. Kondo, "Nature of doped a-Si:H/c-Si interface recombination," J. Appl. Phys., vol. 105, 2009, Art. no. 103707.

[50] T. Matsushita et al., "Semi-insulating polycrystalline-silicon (SIPOS) passivation technology," in Proc. 7th Conf. Solid State Devices, Tokyo, Japan, 1975, pp. 35-40.
[51] F. Feldmann, M. Bivour, C. Reichel, M. Hermle, and S. W. Glunz, "Passivated rear contacts for high-efficiency n-type Si solar cells providing high interface passivation quality and excellent transport characteristics," Sol. Energy Mater. Sol. Cells, vol. 120, pp. 270-274, 2014.

[52] F. Feldmann et al., "Carrier-selective contacts for Si solar cells," Appl. Phys. Lett., vol. 104, 2014, Art. no. 181105.

[53] M. Rienäcker et al., "Recombination behavior of photolithography-free back junction back contact solar cells with carrier-selective polysilicon on oxide junctions for both polarities," Energy Procedia, vol. 92, pp. 412418, 2016.

[54] M. Lenes, R. C. G. Naber, and J. R. M. Luchies, "LPCVD polysilicon passivated contacts for different solar cell concepts," in 6th SiliconPV Conf., Chambéry, France, 2016.

[55] S. Lindekugel, H. Lautenschlager, T. Ruof, and S. Reber, "Plasma hydrogen passivation for crystalline silicon thin-films," in Proc. 29nd Eur. Photovolt. Sol. Energy Conf., Valencia, Spain, 2008, pp. 2232-2235.

[56] B. Nemeth et al., "Polycrystalline silicon passivated tunneling contacts for high efficiency silicon solar cells," J. Mater. Res., vol. 31, no. 6, pp. 671-681, 2016.

[57] M. K. Stodolny et al., "N-type polysilicon passivating contact for industrial bifacial n-type solar cells," Sol Energy Mater. Sol. Cells, vol. 158, pp. 24-28, 2016.

[58] H. C. Card and E. H. Rhoderick, "Studies of tunnel MOS diodes I. Interface effects in silicon Schottky diodes," J. Phys. D: Appl. Phys., vol. 4, pp. 1589-1601, 1971.

[59] I. R. C. Post, P. Ashburn, and G. R. Wolstenholme, "Polysilicon emitters for bipolar transistors: A review and re-evaluation of theory and experiment," IEEE Trans. Electron Devices, vol. 39, no. 7, pp. 1717-1731, Jul. 1992.

[60] H. Steinkemper, F. Feldmann, M. Bivour, and M. Hermle, "Numerical simulation of carrier-selective electron contacts featuring tunnel oxides," IEEE J. Photovolt., vol. 5, no. 5, pp. 1348-1356, Sep. 2015.

[61] M. A. Green, "Effects of pinholes, oxide traps, and surface states on MIS solar cells," Appl. Phys. Lett., vol. 33, pp. 178-180, 1978.

[62] R. Peibst et al., "A simple model describing the symmetric I-V characteristics of p polycrystalline $\mathrm{Si} / \mathrm{n}$ monocrystalline $\mathrm{Si}$, and n polycrystalline Si/p monocrystalline Si junctions," IEEE J. Photovolt., vol. 4, no. 3, pp. 841-850, May 2014.

[63] R. Peibst et al., "Working principle of carrier selective poly-Si/c-Si junctions: Is tunnelling the whole story?" Sol. Energy Mater. Sol. Cells, vol. 158, pp. 60-67, 2016.

[64] U. Römer et al., "Recombination behavior and contact resistance of $\mathrm{n}^{+}$ and $\mathrm{p}^{+}$poly-crystalline Si/mono-crystalline Si junctions," Sol. Energy Mater. Sol. Cells, vol. 131, pp. 85-91, 2014.

[65] O. L. Curtis, J. R. Srour, and K. Y. Chiu, "Hole and electron transport in $\mathrm{SiO}_{2}$ films," J. Appl. Phys., vol. 45, pp. 4506-4513, 1974.

[66] H. Angermann et al., "Effect of wet-chemical substrate pretreatment on electronic interface properties and recombination losses of a-Si:H/c$\mathrm{Si}$ and $\mathrm{a}_{-\mathrm{SiN}} \mathrm{x}: \mathrm{H} / \mathrm{c}-\mathrm{Si}$ hetero-interfaces," Phys. Status Solidi C, vol. 8, pp. 879-882, 2011.

[67] D. Yan, A. Cuevas, J. Bullock, Y. Wan, and C. Samundsett, "Phosphorusdiffused polysilicon contacts for solar cells," Sol. Energy Mater. Sol. Cells, vol. 142, pp. 75-82, 2015.

[68] Y. Tao et al., "Large area tunnel oxide passivated rear contact n-type Si solar cells with $21.2 \%$ efficiency," Prog. Photovolt., Res. Appl., vol. 24, no. 6, pp. 830-835, 2016.

[69] G. Yang, A. Ingenito, N. van Hameren, O. Isabella, and M. Zeman, "Design and application of ion-implanted polySi passivating contacts for interdigitated back contact c-Si solar cells," Appl. Phys. Lett., vol. 108, 2016, Art. no. 033903.

[70] F. Feldmann, C. Reichel, R. Müller, and M. Hermle, "The application of poly-Si/SiO ${ }_{x}$ contacts as passivated top/rear contacts in Si solar cells," Sol. Energy Mater. Sol. Cells, vol. 159, pp. 265-271, 2017.

[71] M. Rüdiger, J. Greulich, A. Richter, and M. Hermle, "Parametrization of free carrier absorption in highly doped silicon for solar cells," IEEE Trans. Electron Devices, vol. 60, no. 7, pp. 2156-2163, Jul. 2013.

[72] J. P. Seif et al., "Strategies for doped nanocrystalline silicon integration in silicon heterojunction solar cells," IEEE J. Photovolt., vol. 6, no. 5, pp. 1132-1140, Sep. 2016.

[73] G. Nogay et al., "Nanocrystalline silicon carrier collectors for silicon heterojunction solar cells and impact on low-temperature device characteristics," IEEE J. Photovolt., vol. 6, no. 6, pp. 1654-1662, Nov. 2016.

[74] K. Ding et al., "Mechanism for crystalline Si surface passivation by the combination of $\mathrm{SiO}_{2}$ tunnel oxide and $\mu \mathrm{c}-\mathrm{SiC}: \mathrm{H}$ thin film," Phys. Status Solidi RRL, vol. 10, pp. 233-236, 2016. 
[75] L. Guo, M. Kondo, M. Fukawa, K. Saitoh, and A. Matsuda, "High rate deposition of microcrystalline silicon using conventional plasma-enhanced chemical vapor deposition," Jpn. J. Appl. Phys., vol. 37, pp. L1116L1118, 1998.

[76] A. H. M. Smets, T. Matsui, and M. Kondo, "High-rate deposition of microcrystalline silicon p-i-n solar cells in the high pressure depletion regime," J. Appl. Phys., vol. 104, 2008, Art. no. 034508.

[77] L. Mazzarella et al., "p-type microcrystalline silicon oxide emitter for silicon heterojunction solar cells allowing current densities above 40 mA/cm²," Appl. Phys. Lett., vol. 106, 2015, Art. no. 023902.

[78] J. Stuckelberger et al., "Passivating electron contact based on highly crystalline nanostructured silicon oxide layers for silicon solar cells," Sol. Energy Mater. Sol. Cells, vol. 158, pp. 2-10, 2016.

[79] G. Nogay et al., "Silicon-rich silicon carbide hole-selective rear contacts for crystalline-silicon-based solar cells," ACS Appl. Mater. Interfaces, vol. 8, pp. 35660-35667, 2016.

[80] G. Nogay et al., "Interplay of annealing temperature and doping in hole selective rear contacts based on silicon-rich silicon-carbide thin films," Sol. Energy Mater. Sol. Cells, vol. 173, pp. 18-24, 2017.

[81] B. Tan and Y. Wu, "Dye-sensitized solar cells based on anatase $\mathrm{TiO}_{2}$ nanoparticle/nanowire composites," J. Phys. Chem. B, vol. 110, pp. 15932-15938, 2006.

[82] F. Di Giacomo et al., "Flexible perovskite photovoltaic modules and solar cells based on atomic layer deposited compact layers and UV-irradiated $\mathrm{TiO}_{2}$ scaffolds on plastic substrates," Adv. Energy Mater., vol. 5, 2015, Art. no. 1401808.

[83] W. Qiu et al., "An electron beam evaporated $\mathrm{TiO}_{2}$ layer for high efficiency planar perovskite solar cells on flexible polyethylene terephthalate substrates," J. Mater. Chem. A, vol. 3, 2015, Art. no. 22824

[84] Y.-C. Tseng, A. U. Mane, J. W. Elam, and S. B. Darling, "Ultrathin molybdenum oxide anode buffer layer for organic photovoltaic cells formed using atomic layer deposition," Sol. Energy Mater. Sol. Cells, vol. 99, pp. 235-239, 2012.

[85] Y. Zhao, A. M. Nardes, and K. Zhu, "Effective hole extraction using $\mathrm{MoO}_{\mathrm{x}} \mathrm{Al}$ contact in perovskite $\mathrm{CH}_{3} \mathrm{NH}_{3} \mathrm{PbI}_{3}$ solar cells," Appl. Phys. Lett., vol. 104, 2014, Art. no. 213906.

[86] B. Liao, B. Hoex, A. G. Aberle, D. Chi, and C. S. Bhatia, "Excellent c-Si surface passivation by low-temperature atomic layer deposited titanium oxide," Appl. Phys. Lett., vol. 104, 2014, Art. no. 253903.

[87] J. Cui et al., "Titanium oxide: A re-emerging optical and passivating material for silicon solar cells," Sol. Energy Mater. Sol. Cells, vol. 158, pp. 115-121, 2016.

[88] J. Melskens, B. W. H. van de Loo, B. Macco, R. W. H. S. Scheerder, and W. M. M. Kessels, "Feasibility study of titanium dioxide as passivating electron-selective contact for crystalline silicon solar cells," in 6th SiliconPV Conf., Chambéry, France, 2016.

[89] X. Yang, P. Zheng, Q. Bi, and K. Weber, "Silicon heterojunction solar cells with electron selective $\mathrm{TiO}_{\mathrm{x}}$ contact," Sol. Energy Mater. Sol. Cells, vol. 150, pp. 32-38, 2016.

[90] X. Yang et al., "High-performance $\mathrm{TiO}_{2}$-based electron-selective contacts for crystalline silicon solar cells," Adv. Mater, vol. 28, pp. 58915897, 2016, doi: 10.1002/adma.201600926.

[91] A. F. Thomson and K. R. McIntosh, "Light-enhanced surface passivation of $\mathrm{TiO}_{2}$-coated silicon," Prog. Photovolt., Res. Appl., vol. 20, pp. 343349, 2012.

[92] T. Matsui, M. Bivour, P. Ndione, P. Hettich, and M. Hermle, "Investigation of atomic-layer-deposited $\mathrm{TiO}_{\mathrm{x}}$ as selective electron and hole contacts to crystalline silicon," Energy Procedia, vol. 124, pp. 628-634, 2017.

[93] X. Yang, K. Weber, Z. Hameiri, and S. de Wolf, "Industrially feasible, dopant-free, carrier-selective contacts for high-efficiency silicon solar cells," Prog. Photovolt., Res. Appl., vol. 25, pp. 896-904, 2017, doi: 10.1002/pip.2901.

[94] C. Battaglia et al., "Silicon heterojunction solar cell with passivated hole selective $\mathrm{MoO}_{\mathrm{x}}$ contact," Appl. Phys. Lett., vol. 104, 2014, Art. no. 113902.

[95] B. Macco, M. F. J. Vos, N. F. W. Thissen, A. A. Bol, and W. M. M. Kessels, "Low-temperature atomic layer deposition of $\mathrm{MoO}_{\mathrm{x}}$ for silicon heterojunction solar cells," Phys. Status Solidi RRL, vol. 9, pp. 393-396, 2015.

[96] J. Geissbühler et al., "22.5\% efficient silicon heterojunction solar cell with molybdenum oxide hole collector," Appl. Phys. Lett., vol. 107, 2015, Art. no. 081601
[97] L. G. Gerling et al., "Transition metal oxides as hole-selective contacts in silicon heterojunction solar cells," Sol. Energy Mater. Sol. Cells, vol. 145, pp. 109-115, 2016.

[98] L. G. Gerling, C. Voz, R. Alcubilla, and J. Puigdollers, "Origin of passivation in hole-selective transition metal oxides for crystalline silicon heterojunction solar cells," J. Mater. Res., vol. 22, no. 2, pp. 260-268, 2016.

[99] J. Bullock, A. Cuevas, T. G. Allen, and C. Battaglia, "Molybdenum oxide $\mathrm{MoO}_{\mathrm{x}}$ : A versatile hole contact for silicon solar cells," Appl. Phys. Lett., vol. 105, 2014, Art. no. 232109.

[100] C. Battaglia et al., "Hole selective $\mathrm{MoO}_{\mathrm{x}}$ contact for silicon solar cells," Nano Lett., vol. 14, pp. 967-971, 2014

[101] M. Mews, A. Lemaire, and L. Korte, "Sputtered tungsten oxide as hole contact for silicon heterojunction solar cells," IEEE J. Photovolt., vol. 7, no. 5, pp. 1209-1215, Sep. 2017, doi: 10.1109/JPHOTOV.2017.2714193.

[102] M. Bivour, J. Temmler, H. Steinkemper, and M. Hermle, "Molybdenum and tungsten oxide: High work function wide band gap contact materials for hole selective contacts of silicon solar cells," Sol. Energy Mater. Sol. Cells, vol. 142, pp. 34-41, 2015.

[103] G. Masmitjà et al., " $\mathrm{V}_{2} \mathrm{O}_{\mathrm{x}}$-based hole-selective contacts for c-Si interdigitated back-contacted solar cells," J. Mater. Chem. A, vol. 5, pp. 9182 9189, 2017, doi: 10.1039/C7TA01959A

[104] M. Mews, L. Korte, and B. Rech, "Oxygen vacancies in tungsten oxide and their influence on tungsten oxide/silicon heterojunction solar cells," Sol. Energy Mater. Sol. Cells, vol. 158, pp. 77-83, 2016.

[105] F. Feldmann et al., "High and low work function materials for passivated contacts," Energy Procedia, vol. 77, pp. 263-270, 2015.

[106] J. Bullock et al., "Efficient silicon solar cells with dopant-free asymmetric heterocontacts," Nature Energy, vol. 1, 2016, Art. no. 15031.

[107] J. Bullock et al., "Proof-of-concept p-type silicon solar cells with molybdenum oxide local rear contacts," IEEE J. Photovolt., vol. 5, no. 6, pp. 1591-1595, Nov. 2015.

[108] M. F. J. Vos, B. Macco, N. F. W. Thissen, A. A. Bol, and W. M M. Kessels, "Atomic layer deposition of molybdenum oxide from $\left(\mathrm{N}^{\mathrm{t}} \mathrm{Bu}\right)_{2}\left(\mathrm{NMe}_{2}\right)_{2} \mathrm{Mo}$ and $\mathrm{O}_{2}$ plasma," J. Vac. Sci. Technol. A, vol. 34 2016, Art. no. $01 \mathrm{~A} 103$.

[109] M. Bivour, B. Macco, J. Temmler, W. M. M. Kessels, and M. Hermle, "Atomic layer deposited molybdenum oxide for the hole-selective contact of silicon solar cells," Energy Procedia, vol. 92, pp. 443-449, 2016.

[110] M. Bivour et al., "Principles of carrier-selective contacts based on induced junctions," in 33rd Eur. Photovolt. Sol. Energy Conf., Amsterdam, The Netherlands, 2017, pp. 348-352.

[111] M. Greiner and Z.-H. Lu, "Thin-film metal oxides in organic semiconductor devices: Their electronic structures, work functions and interfaces," NPG Asia Mater., vol. 5, p. e55, 2013.

[112] K. Kajiyama and Y. Furukawa, "Electrical and optical properties of SnO2-Si heterojunctions," Jpn. J. Appl. Phys., vol. 6, pp. 905-906, 1967.

[113] D. L. Young et al., "Carrier selective, passivated contacts for high efficiency silicon solar cells based on transparent conducting oxides," Energy Procedia, vol. 55, pp. 733-740, 2014.

[114] F. Wang et al., "Silicon solar cells with bifacial metal oxides carrier selective layers," Nano Energy, vol. 39, pp. 437-443, 2017.

[115] B. W. H. van de Loo, "Atomic layer deposition for surface passivation of crystalline silicon solar cells," Ph.D. dissertation, Eindhoven Univ. Technol., Eindhoven, The Netherlands, 2017.

[116] B. Hoex, S. B. S. Heil, E. Langereis, M. C. M. van de Sanden, and W M. M. Kessels, "Ultralow surface recombination of c-Si substrates passivated by plasma-assisted atomic layer deposited $\mathrm{Al}_{2} \mathrm{O}_{3}$, , Appl. Phys. Lett., vol. 89, 2006, Art. no. 042112.

[117] B. Hoex et al., "Excellent passivation of highly doped p-type Si surfaces by the negative-charge-dielectric $\mathrm{Al}_{2} \mathrm{O}_{3}$," Appl. Phys. Lett., vol. 91, 2007, Art. no. 112107

[118] F. Lin, B. Hoex, Y. H. Koh, J. J. Lin, and A. G. Aberle, "Low-temperature surface passivation of moderately doped crystalline silicon by atomiclayer-deposited hafnium oxide films," Energy Procedia, vol. 15, pp. 84 90, 2012.

[119] J. Cui, Y. Wan, Y. Cui, Y. Chen, and A. Cuevas, "Highly effective electronic passivation of silicon surfaces by atomic layer deposited hafnium oxide," Appl. Phys. Lett., vol. 110, 2017, Art. no. 021602.

[120] Y. Wan, J. Bullock, and A. Cuevas, "Passivation of c-Si surfaces by ALD tantalum oxide capped with PECVD silicon nitride," Sol. Energy Mater. Sol. Cells, vol. 142, pp. 42-46, 2015.

[121] X. Zhang, Y. Wan, J. Bullock, T. Allen, and A. Cuevas, "Low resistance Ohmic contact to $p$-type crystalline silicon via nitrogen-doped copper oxide films," Appl. Phys. Lett., vol. 109, 2016, Art. no. 052102. 
[122] M. J. Sailor et al., "Thin films of n-Si/poly- $\left(\mathrm{CH}_{3}\right)_{3}$ Si-cyclotatetraene: Conducting-polymer solar cells and layered structures," Science, vol. 249, no. 4973, pp. 1146-1149, 1990.

[123] S. Avasthi, S. Lee, Y.-L. Loo, and J. C. Sturm, "Role of majority and minority carrier barriers silicon/organic hybrid heterojunction solar cells,' Adv. Mater., vol. 23, pp. 5762-5766, 2011.

[124] D. Zielke, A. Pazidis, F. Werner, and J. Schmidt, "Organic-silicon heterojunction solar cells on n-type silicon wafers: The BackPEDOT concept,' Sol. Energy Mater. Sol. Cells, vol. 131, pp. 110-116, 2014.

[125] D. Zielke et al., "Organic-silicon solar cells exceeding 20\% efficiency," Energy Procedia, vol. 77, pp. 331-339, 2015.

[126] S. Jäckle et al., "Potential of PEDOT:PSS as a hole selective front contact for silicon heterojunction solar cells," Sci. Rep., vol. 7, 2017, Art. no. 2170 .

[127] R. Gogolin, D. Zielke, W. Lövenich, R. Sauer, and J. Schmidt, "Silicon heterojunction solar cells combining an a-Si:H(n) electron-collector with a PEDOT:PSS hole-collector," Energy Procedia, vol. 92, pp. 638-643, 2016.

[128] H. Yan et al., "A high-mobility electron-transporting polymer for printed transistors," Nature, vol. 457, pp. 679-687, 2009.

[129] Y. Li et al., "Elucidation of the electron injection mechanism of evaporated cesium carbonate cathode interlayer for organic light-emitting diodes," Appl. Phys. Lett., vol. 90, 2007, Art. no. 012119.

[130] C. Ganzorig, K. Suga, and M. Fujihira, "Alkali metal acetates as effective electron injection layers for organic electroluminescent devices," Mater. Sci. Eng., vol. B85, pp. 140-143, 2001.

[131] L. S. Hung, C. W. Tang, and M. G. Mason, "Enhanced electron injection in organic electroluminescence devices using an $\mathrm{Al} / \mathrm{LiF}$ electrode," Appl. Phys. Lett., vol. 70, no. 2, pp. 152-154, 1997.

[132] M. G. Helander, Z. B. Wang, L. Mordoukhovski, and Z. H. Lu, "Comparison of Alq3/alkali-metal fluoride/Al cathodes for organic electroluminescent devices," J. Appl. Phys., vol. 104, 2008, Art. no. 094510.

[133] Y. Wan et al., "Conductive and stable magnesium oxide electron-selective contacts for efficient silicon solar cells," Adv. Energy Mater., vol. 7, 2017, Art. no. 1601863.

[134] Y. Wan et al., "Magnesium fluoride electron-selective contacts for crystalline silicon solar cells," ACS Appl. Mater. Interfaces, vol. 8, pp. 1467114677,2016

[135] J. Bullock et al., "Lithium fluoride based electron contacts for high efficiency n-type crystalline silicon solar cells," Adv. Energy Mater. vol. 6, 2016, Art. no. 1600241 .

[136] Y. Wan et al., "A magnesium/amorphous silicon passivating contact for n-type crystalline silicon solar cells," Appl. Phys. Lett., vol. 109, 2016, Art. no. 113901.

[137] T. G. Allen et al., "Calcium contacts to n-type crystalline silicon solar cells," Prog. Photovolt., Res. Appl., vol. 25, pp. 636-644, 2016, doi: 10.1002/pip.2838.

[138] T. G. Allen et al., "Low resistance $\mathrm{TiO}_{2}$-passivated calcium contacts for crystalline silicon solar cells," in Proc. 43rd IEEE Photovolt. Spec. Conf., Portland, OR, USA, 2016, pp. 230-233.

[139] A. Fell, "A free and fast three-dimensional/two-dimensional solar cell simulator featuring conductive boundary and quasi-neutrality approximations," IEEE Trans. Electron Devices, vol. 60, no. 2, pp. 733-738, Feb. 2013.

[140] J. H. Zhao, A. H. Wang, and M. A. Green, "24.5\% efficiency silicon PERT cells on MCZ substrates and $24.7 \%$ PERL cells on FZ substrates," Prog. Photovolt., Res. Appl., vol. 7, pp. 471-474, 1999.

[141] E. Cornagliotti et al., "Large-area n-type PERT solar cells featuring rear $\mathrm{p}^{+}$emitter passivated by $\mathrm{ALD} \mathrm{Al}_{2} \mathrm{O}_{3}$," IEEE J. Photovolt., vol. 5, no. 5, pp. 1366-1372, Sep. 2015.

[142] A. Urueña et al., "Beyond 22\% large area n-type silicon solar cells with front laser doping and a rear emitter," in Proc. 31st Eur. Photovolt. Sol. Energy Conf., Hamburg, Germany, 2015, pp. 410-413.

[143] A. Fell et al., "Input parameters for the simulation of silicon solar cells in 2014," IEEE J. Photovolt., vol. 5, no. 4, pp. 1250-1263, Jul. 2015.

[144] K. Nakano, Kaneka Corporation, Japan, private communication, 2016.

[145] A. Richter, S. W. Glunz, F. Werner, J. Schmidt, and A. Cuevas, "Improved quantitative description of Auger recombination in crystalline silicon,' Phys. Rev. B, vol. 86, 2012, Art. no. 165202.

[146] J. Bullock et al., "Amorphous silicon enhanced metal-insulatorsemiconductor contacts for silicon solar cells," J. Appl. Phys., vol. 116, 2014, Art. no. 163706.
[147] R. Brendel and R. Peibst, "Contact selectivity and efficiency in crystalline silicon photovoltaics," IEEE J. Photovolt., vol. 6, no. 6, pp. 1413-1420, Nov. 2016.

[148] C. M. Palumbiny et al., "Molecular reorientation and structural changes in cosolvent-treated highly conductive PEDOT:PSS electrodes for flexible indium tin oxide-free organic electronics," J. Phys. Chem. C, vol. 118, pp. 13598-13606, 2014.

[149] B. Macco, H. C. M. Knoops, and W. M. M. Kessels, "Electron scattering and doping mechanisms in solid-phase-crystallized $\operatorname{In}_{2} \mathrm{O}_{3}: \mathrm{H}$ prepared by atomic layer deposition," ACS Appl. Mater. Interfaces, vol. 7, pp. 16723 16729, 2015.

[150] B. Macco, Y. Wu, D. Vanhemel, and W. M. M. Kessels, "High mobility $\mathrm{In}_{2} \mathrm{O}_{3}: \mathrm{H}$ transparent conductive oxides prepared by atomic layer deposition and solid phase crystallization," Phys. Status Solidi RRL, vol. 8, pp. 987-990, 2014.

[151] B. Macco et al., "Influence of transparent conductive oxides on passivation of a-Si:H/c-Si heterojunctions as studied by atomic layer deposited Al-doped ZnO," Semicond. Sci. Technol., vol. 29, 2014, Art. no. 122001.

[152] B. Macco et al., "Atomic layer deposition of high-mobility hydrogendoped zinc oxide," Sol. Energy Mater. Sol. Cells, vol. 173, pp. 111-119, 2017, doi: 10.1016/j.solmat.2017.05.040.

[153] M. Morales-Masis, S. Martin de Nicolas, J. Holovský, S. de Wolf, and C. Ballif, "Low-temperature high-mobility amorphous IZO for silicon heterojunction solar cells," IEEE J. Photovolt., vol. 5, no. 5, pp. 13401347, Sep. 2015.

[154] S. Reiter et al., "Parasitic absorption in polycrystalline Si-layers for carrier-selective front junctions," Energy Procedia, vol. 92, pp. 199-204, 2016.

[155] K. R. McIntosh and S. C. Baker-Finch, "OPAL 2: Rapid optical simulation of silicon solar cells," in Proc. 38th IEEE Photovolt. Spec. Conf., Austin, TX, USA, 2012, pp. 265-271.

[156] G. Dingemans and W. M. M. Kessels, "Status and prospects of $\mathrm{Al}_{2} \mathrm{O}_{3}$ based surface passivation schemes for silicon solar cells," J. Vac. Sci. Technol. A, vol. 30, 2012, Art. no. 040802.

[157] Z. Wang et al., "Advanced PERC and PERL production cells with $20.3 \%$ record efficiency for standard commercial p-type silicon wafers," Prog. Photovolt., Res. Appl., vol. 20, pp. 260-268, 2012.

[158] L. Tous et al., "Evaluation of advanced p-PERL and n-PERT large area silicon solar cells with $20.5 \%$ energy conversion efficiencies," Prog. Photovolt., Res. Appl., vol. 23, pp. 660-670, 2015.

[159] "Imec develops bifacial n-PERT solar cell with a record 22.8 percent front-side efficiency," press release, Apr. 18 2017. [Online]. Available: https://www.imec-int.com/en/articles/imec-develops-bifacial-n-pertsolar-cell-with-a-record-22-8-percent-front-side-efficiency

[160] "JinkoSolar's monocrystalline PERC solar cell efficiency of $23.45 \%$ verified," press release, Nov. 8 2017. [Online]. Available: https://www.jinkosolar.com/press_detail_1395.html

[161] A. Louwen, W. van Sark, R. Schropp, and A. Faaij, "A cost roadmap for silicon heterojunction solar cells," Sol. Energy Mater. Sol. Cells, vol. 147, pp. 295-314, 2016.

[162] International Technology Roadmap for Photovoltaic (ITRPV), 8th ed., 2017.

[163] M. K. Stodolny et al., "Material properties of LPCVD processed n-type polysilicon passivating contacts and its application in PERPoly industrial bifacial solar cells," Energy Procedia, vol. 124, pp. 635-642, 2017.

[164] T. Koida, H. Fujiwara, and M. Kondo, "High-mobility hydrogen-doped $\mathrm{In}_{2} \mathrm{O}_{3}$ transparent conductive oxide for $-\mathrm{Si}: \mathrm{H} / \mathrm{c}-\mathrm{Si}$ heterojunction solar cells," Sol. Energy Mater. Sol. Cells, vol. 93, pp. 851-854, 2009.

[165] B. Demaurex et al., "Atomic-layer-deposited transparent electrodes for silicon heterojunction solar cells," IEEE J. Photovolt., vol. 4, no. 6, pp. 1387-1396, Nov. 2014

[166] P. Carroy et al., "Analysis of different front and back TCO on heterojunction solar cells," in Proc. 31st Eur. Photovolt. Sol. Energy Conf., Hamburg, Germany, 2015, pp. 359-364.

Authors' photographs and biographies not available at the time of publication. 